\title{
Development Of An Advanced Continuous Mild Gasification Process For The Production Of Co-Products
}

\author{
Final Report \\ September 1987- September 1996
}

\author{
Work Performed Under Contract No.: DE-AC21-87MC24116 \\ For \\ U.S. Department of Energy \\ Office of Fossil Energy \\ Morgantown Energy Technology Center \\ P.O. Box 880 \\ Morgantown, West Virginia 26507-0880
}

By

Coal Technology Research Corp.

103 Thomas Road

Bristol, Virginia 24201 


\section{Disclaimer}

This report was prepared as an account of work sponsored by an agency of the United States Government. Neither the United States Government nor any agency thereof, nor any of their employees, makes any warranty, express or implied, or assumes any legal liability or responsibility for the accuracy, completeness, or usefulness of any information, apparatus, product, or process disclosed, or represents that its use would not infringe privately owned rights. Reference herein to any specific commercial product, process, or service by trade name, trademark, manufacturer, or otherwise does not necessarily constitute or imply its endorsement, recommendation, or favoring by the United States Government or any agency thereof. The views and opinions of authors expressed herein do not necessarily state or reflect those of the United States Government or any agency thereof. 


\section{EXECUTIVE SUMMARY}

Any profitable mild coal gasification process has to have a profitable end use for the major co-product, char, The char represents about 70 percent of the total product yield. The only viable use for the char is in the production of formed coke.

Early work to develop formed coke used char from a pilot plant sized mild gasification unit (MGU). The MGU was based on commercial units of the COALITE plant in England which has operated for over 50 years.

Formed coke was made at a bench-scale production level using MGU chars from different coals. Emphasis was on using local coals available in large quantities at economical costs since commercialization of the coal gasification process was the final objective. An evolutionary formed coke development process over a two-year period resulted in formed coke production at bench-scale levels that met metallurgical industries' specifications, In an ASTM D5341 reactivity test by a certified lab, the coke tested CRI 30.4 and CSR 67.0 which is excellent. The standard is CRI $<32$ and CSR $>55$.

In 1991, a continuous 1000 pounds per hour coal feed mild coal gasification pilot plant (CMGU) was completed. The gasification unit is a heated unique screw conveyor designed to continuously: (1) process plastic coal; (2) vent volatiles generated by pyrolysis of coal; and (3) convert the plastic coal to free flowing char. The screw reactor auxiliary components are basic solids materials handling equipment. The normal amount of start-up problems and necessary equipment modifications for the "first of its kind" unit were experienced. The screw reactor will convert coal to char and volatile coproducts at a rate greater than 1000 pounds per hour of coal feed.

Formed coke from CMGU char is comparable to that from the MGU char. Form coke development work using the CMGU char was concentrated on making foundry coke in quantities that permitted testing in commercial operations, A formed coke pilot plant was assembled from used equipment in available space in one of the two CMGU buildings. Completed in 1995, test runs up to 20 tons of foundry coke were produced, Three formed coke tests at commercial foundries were successful. The last two were joint tests with General Motors. In all of the cupola tests, the iron temperature and composition data indicated that the formed coke performed satisfactorily. No negative change in the way the cupola performed was noticed. The last 20-ton test was 100 percent CTC/DOE coke. Temperature readings were excellent. Back pressures were low and constant. (Back pressure tells the operator if the coke is holding its shape and holding the burden of the material,) With conventional coke in this cupola charging rates were 10 charges per hour. The formed coke charges were 11 to 12 charges per hour. This equates to a higher melt rate, A 10 percent increase in cupola production would be a major advantage. 
Development work including pilot plant scale production, is considered really successful only if commercialization of the project is realized. Development efforts on coal mild gasification have provided the basis for this next step in gaining the acceptance of a better way to provide coke for the world's metal industry. 
TABLE OF CONTENTS

\section{EXECUTIVE SUMMARY}

\section{PAGE}

INTRODUCTION

TASK 3. BENCH-SCALE CHAR UPGRADING STUDY 3

TASK 4. PDU DESIGN

TASK 5. CONTINUOUS BRIQUETTING AND COKING

APPENDIX

Figures 1-13

Tables 1-13 


\section{INTRODUCTION}

Petroleum currently accounts for over 42 percent of the total energy consumption in the United States; over 40 percent of the petroleum consumed in the United States is imported from foreign countries. The remaining oil reserve available in the United States is less than 6 percent of proven recoverable fossil energy reserves while over 90 percent of the proven recoverable reserves are coal'. Total coal resources in the United States are estimated to be more than 3.9 trillion tons ${ }^{2}$. Just the demonstrated reserves, that is, the deposits that are proven and can be economically mined using today's technologies and mining techniques amount to 488 billion tons. At an annual production rate of 900 million tons per year, the demonstrated reserves alone will last more than 500 years. In view of the very abundant coal reserves and limited petroleum reserves, it would seem prudent to make good use of coal in our evermore difficult pursuit of energy independence.

Devising a continuous reactor system that can deliver a good quality co-products which require only minimal upgrading before being marketed is a major challenge. At present, mild gasification reactor configurations tend to fall into two broad categories: circulating or fluidized bed types characterized by high heating rates (up to $10,000^{\circ} \mathrm{C}$ per second, or fixed or moving bed types characterized by slow (on the order of 0,2 to $0.5^{\circ} \mathrm{C}$ per second) heating rates. Circulating or fluidized-bed types produce high liquid yields at the expense of quality. Fixed or moving-bed types produce better quality liquids but in lesser quantities. An optimum reactor is envisioned as one which avoids the secondary reactions associated with slow heating rates and the quality problems associated with high heating rates. Importantly, an optimum reactor would be capable of processing highly caking coals. The reactor concept under investigation in this effort is an advanced derivative of a reactor once used in prior commercial practice which approaches the characteristics of an optim urn reactor.

It is important that a mild gasification reactor interface easily with the subsequent product upgrading steps in which the market value of the products is enhanced, Upgrading and marketing of the char are critical to the overall economics of a mild gasification plant because char is the major product ( 65 to 75 percent of the coal feedstock). In the past, the char product was sold as a "smokeless" fuel, but in today's competitive markets the best price for char as a fuel for steam generation would be that of the parent coal, Substantially higher prices could be obtained for char upgraded into

\footnotetext{
'T. R. Scollon, "An Assessment of Coal Resources, " CHEMICAL ENGINEERING PROGRESS, June 1977, pp. 25-30.

2J.M. Eggleston, " Bituminous Coal Marketing, " presented at
the Third U.S.A.-Korea Joint Workshop on Coal Utilization
Technology, Pittsburgh, October 5-7, 1986 .
}


products such as metallurgical coke, graphite, carbon electrode feedstock or a slurry fuel replacement for No, 6 fuel oil. In this effort, upgrading techniques are being developed to address these premium markets. Liquid products can similarly be upgraded to high market value products such as high-density fuel, chemicals, binders for form coke, and also gasoline and diesel blending stocks. About half of the non-condensable fuel gases produced by the gasification process will be required to operate the process; the unused portion could be upgraded into value-added products or used as fuel either internally or in "across the fence" sales.

The primary objective of this project is to develop an advanced continuous mild gasification process and product upgrading processes which will be capable of eventual commercialization. The program consists of four tasks. Task 1 is a literature survey of mild gasification processes and product upgrading methods and also a market assessment of markets for mild gasification products. Based on the literature survey, a mild gasification process and char upgrading method will be identified for further development, Task 2 is a bench-scale investigation of mild gasification to generate design data for a larger scale reactor. Task 3 is a bench-scale study of char upgrading to value added products. Task 4 is being implemented by building and operating a 1000 pounds per hour demonstration facility. Task 4 also includes a technical and economic evaluation based on the performance of the mild gasification demonstration facility. 


\section{TASK 3. BENCH-SCALE CHAR UPGRADING STUDY}

Char upgrading considered several possible products which could be value added or upgrades, The best commercial candidate is coke. Work on coke took an evolutionary path to the ultimate conclusion.

1988:

Early in this project it became evident that char upgrading was crucial to this project. Char, representing about 65-75 percent of the coal feedstock (bituminous) in yield, is by far the major co-product from mild coal gasification processing. Therefore, successful char upgrading to a higher market value product, such as coke, is critical in terms of the overall economics of the mild gasification technology.

The original bench-scale coke oven was designed and built in 1988, This oven is a closed, insulated chamber with outside dimensions of approximately 5 feet $x 6$ feet $x$ 3 feet which is heated by radiant heaters to temperatures of 1800 to $1900^{\circ} \mathrm{F}$. A sketch of the coke oven is shown in the Appendix, Figure 1.

1989:

Through our bench-scale coke oven, testing operations and a cooperative testing program with outside laboratories were initiated, Three trips were made to Komarek Research, the first in February, the second in April, and the third in July. The objective of the tests was to produce a sufficiently strong green briquette that could be carbonized to produce a metallurgical grade form coke. The conditions of the second series of briquetting tests were based on results from the first series of briquetting tests conducted at Komarek. Conditions for the third series of briquetting tests were based on results from the previous two series of tests at Komarek. The green briquettes made at Komarek were then brought back and coked at CTC.

In order to speed up the turnaround time and to reduce cost of the char briquetting, coking, and testing, smaller bench-scale pelletizing tests were conducted using various blends and pelletizing conditions, A small steel cylinder with a removable bottom plate was fabricated in order to produce 1 inch $\times 1$ inch pellets with a 10-ton shop press. Two series of the 1 inch $\times 1$ inch cylindrical pellets were produced, coked and tested for strength. Char, coking coal and pitch were formulated in varying percentages; and then the cylinders were formed at various hydraulic pressures under similar coking conditions in the bench scale furnace, Later work indicated that data obtained on 1 inch $\times 1$ inch pellets would not apply well to the $1.625 \times 0.800 \times 0,625$ briquettes.

From the data on these 1 inch $\times 1$ inch pellets, a mathematical model was developed using STRAGRAPHICS software. Using the data, a three dimensional surface plot was generated showing the influence of binder coal and pitch on pellet strength. The graph 
is impressive but it needs to be constructed with data from the briquettes which would be used in the blast furnace rather than the 1 inch $x 1$ inch pellets. Also, to measure quality probably it would be better to use CSR or CRI than crushing strength. A plot of crushing strength versus percent coal and percent pitch is shown in the Appendix, Figure 2.

The shakedown testing of the bench-scale coke oven was completed in January, 1989. These early test programs were the start of the research on char briquetting and coke product analysis. Valuable results were obtained which helped product analysis, Valuable results also were obtained which helped zero-in on the suitable char-coking parameters and operating conditions for successful coke production from char. The results obtained from coke from char testing in 1989 could be highlighted as follows:

- It is not feasible to make coke from char merely by heating the char to coking temperature without modification. The two bench-scale coke furnace tests confirmed this, A physical examination of the product showed that the coke was too brittle and lacked the strength characteristics of a typical metallurgical coke. Char samples were sent to UEC Coal and Coke Laboratory for analysis. This analysis confirmed the sample was too weak with a stability of 36.6 (standard is 58 mininum) and a hardness of 48,7 (standard is 67 mininum).

- Briquetting of char before coking helps enhance the product coke, This would later prove to be a major breakthrough that would greatly contribute to the final success. Initial char briquetting tests were conducted at K. R. Komarek Research, Inc. in February, 1989. The first tests were done on Komarek's B$100 \mathrm{~A}$ briquette which gave a briquette size of 1.625 inches $x 0.813$ inch $x$ 0.625 inch, The second set of tests was conducted on a Komarek B-220A machine which was eventually acquired and moved to CTC. This machine produces briquettes of 1.75 inches $\times 1,375$ inches $\times 0,875$ inch which is a reasonable size for blast furnace coke.

Important char briquetting factors influence binder quality and binder content, briquetting pressure and temperature, blending of coking coal to serve as contributing binding agent during coking, char and coking coal particle size, and total volatile matter content of the raw material blend, From the very beginning some of the important variables were identified based on knowledge and experience of the staff and the research done in Task 1.

Essential char (briquette) coking conditions include proper nitrogen, temperature, and residence time, After these briquettes were coked they were sent to UEC for analysis. The CRI was 46.3 (should be $<32$ ) and the CSR was 2.0 (should be $>55$ ). The analyses data are shown in the Appendix, Table 1. 
In 1989 these variables contributing to coke quality were being identified but exactly what were the best characteristics were yet to be identified. It is interesting to note that in 1989 great emphasis was put on green briquette strength, At the end of this project it was revealed that green briquette strength is unimportant and has no relation to the strength of the coke briquette. The green briquette only has to be strong enough to survive handling. It is a credit to the early work done at CTC that by the end of 1989 the CTC coke had met the stability test, had almost met the hardness test, and almost met the CRI. The data are shown in the Appendix, Table 2 and Table 3.

1990:

Some significant advances in converting mild gasification char to specification blast furnace coke were achieved early. A briquette test plan was developed for making coke on a semi-production scale at the plant of K. R. Komarek in Anniston, Alabama. These tests were conducted in January, 1990. The briquettes that were made duplicated the better 1 inch $x 1$ inch pellets made in testing at CTC in 1989. Green briquettes were sent to UEC for coking and analysis of their coke quality. Green briquettes were also sent to the CTC laboratory for coking and then forwarded to UEC for analysis of their coke quality, The results were disappointing because the desired ratings for CSR, CRI and stability were not achieved. However, one important new finding became evident: the briquettes coked by UEC exhibited poor quality compared to the briquettes coked at CTC. This is attributed to the faster heating rate and/or water quenching at UEC compared to the slower heating rate at CTC.

Late in the First Quarter of 1990, CTC obtained the Komarek B-220 briquetting machine used at Komarek in earlier work. With this machine semi-production scale experiments on formed coke briquetting could be conducted. The machine is sized so that individual experiments on small scale production could be performed. The size of the briquette pockets allows for analysis and use in blast furnaces. The briquette machine has allowed work to proceed in an earnest and more efficient fashion toward making suitable blast furnace coke. Photographs of the machine appear in the Appendix, Figures 3 and 4.

At this point it became clear that the best quality meter for blast furnace coke was the Japanese CRI/CSR test. This test was later adopted by the ASTM. The CTC targets for commercial blast furnace coke using this test were:

Coke Reactivity Index (CRI)

Target: $<32$

Coke Strength After Reaction (CSR)

Target: $>55$ 
The Coke Reactivity Index (CRI) is determined by reacting 200 grams of plus 3/4-inch by minus $7 / 8$-inch dry coke in an atmosphere of flowing carbon dioxide for two hours at $1100^{\prime} \mathrm{C}\left(2012^{\circ} \mathrm{F}\right)$. The $\mathrm{CR}$ is reported as the percent weight loss of the coke sample in the test. The Coke Strength After Reaction (CSR) is determined by tumbling the coke from the CRI test in a drum for 600 revolutions at 20 RPM, The cumulative percent of plus $3 / 8$-inch coke after tumbling is reported as the CSR.

Test methods which approximated the procedures above were used to accelerate the work and serve as screening procedures. The approximate test methods reduced analytical turnaround time from two weeks to one day for each test run. Costs of testing were correspondingly reduced. This testing method could not be directly compared to the standard test but it gave a relative quality figure. Promising samples were sent to an independent test laboratory where $\mathrm{CRI}$ and CSR tests were made. A range of other coke briquette samples were also tested by the independent laboratory to allow correlation of their test results with the CTC test results since the approximate test procedures used by CTC would not give the same values for CRI and CSR. A total of 41 test runs were made in a seven-month period.

It was becoming evident that formed coke is quite different from conventional coke in terms of criteria for feedstock and manufacturing practice. While there are many articles on conventional coke with some carryover, obtaining good information on formed coke was difficult. There was indication that reactivity is a function of the type and maceral content of the feedstock coal, which relates back to the rank, type, and grade of the coal. This would help in the selection of the parent coal for char production so that oil yield as well as the desired formed coke quality maybe obtained. An information gap concerns the fate of the macerals during mild gasification.

The parameters investigated in the coking test program included the char/coker heat and temperature history, the raw material analysis, and the raw material recipe. In general, quality coke could not be made with char and hard pitch alone; and more promising results were obtained by using a binder coal in the coke formulation. This very empirical approach appeared to be effective for this type of experimenting since the large number of variables could not have been tested in a reasonable time period. Later when the basic variable were determined, the finer variables were investigated. In 1990, 70 small scale coking tests were made with batch-produced mild gasification char in the bench-scale electric furnace, Candidate formulations were chosen for coke meeting blast furnace specifications. In mid-1990 our coke quality targets were achieved with a $31.0 \mathrm{CR}$ I and a $62.1 \mathrm{CSR}$. These test results were confirmed by an independent testing laboratory, The test results are shown in the Appendix, Table 4.

Three tests were completed with the purpose of studying the effect of the thermal history of the char feedstock on the coke. Separate batches of coal were heated to 800, 950, and $1100 " F$ in the batch MGU. The resultant char was then used as feedstock to form green briquettes which were coked and then tested by CTC for Japanese Coke 
Reactivity (CRI) and Strength After Reaction (CSR). Identical formulations of 65 percent char, 25 percent binder coal, 5 percent pitch and 5 percent asphalt pitch were used in each briquetting tests.

The results shown below indicate that the char heated to $950^{\circ} \mathrm{F}$ provides the best coke of this series.

$\begin{array}{lll}\text { Test } & \text { CRI } & \text { CSR } \\ \text { 800 F Char } & 22.8 & 83,9 \\ \text { 950F Char } & 18.8 & 86,0 \\ \text { 1100"F Char } & 23.5 & 83.6\end{array}$

At this point in time CTC's tests for CRI and CSR were not with the proper equipment to correspond to the certified laboratories but it did give a relative rank and showed which coke sample was of superior quality. This series of tests showed that the less reactive char would not make the less reactive coke. In the reaction of the coking process the $950^{\circ} \mathrm{F}$ char reacting with the binder coal, pitch and asphalt made the least reactive coke.

Economic evaluations were being conducted in 1990 to determine the probability of success of a commercial plant using the CTC/DOE technology. Preliminary economic evaluations made at various times during the project have always shown economic viability. If the CTC process produces good blast furnace coke in quantity, a market opportunity is available for its sale. Blast furnace coke is in short supply in the United States due to the retirement of aging ovens, Steel mills are now buying over $2,000,000$ tons per year of coke from foreign sources at around $\$ 110$ per ton (blast furnace coke).

About 70 percent of the coal fed to the continuous reactor becomes char. Thus, 1000 pounds of coal to the reactor becomes 700 pounds of char and after the addition of 300 pounds of other raw materials, the yield is 1000 pounds of coke. It was evident that there is a sharp upgrading in value from $\$ 40$ perton for coal to $\$ 110$ per ton for blast furnace coke. This potential plus the value added by the coal liquids converted to transportation fuels strongly suggests that the CTC process has attractive economics for today's markets.

1991:

Testing various coke recipes and process enhancements continued through the year, At year's end the number of different tests was up to 120 . After the quality standards were met in 1991, work then focused on maintaining quality while improving the economic variables. Some of the things looked at were parent coals for both the char and the binder coal and many petroleum and coal derived bitumen. 
The relationship between the strength of the green briquettes to the coke briquettes to the Strength After Reaction (CSR) of the coke was studied. Crush strength is a measure of the compression strength of the green briquettes before and after calcining. A minimum green crush strength, not precisely defined, is needed to prevent breakup of the green briquettes in commercial calcining and handling. After calcining, the briquettes need coke crush strength, also not yet exactly defined, for shipping and handling the briquettes prior to charging in the blast furnaces. Finally, there is a third strength called "Coke Strength After Reaction" (CSR) that is considered very important and the best measure of quality in blast furnace coke. The desired figure for CSR is defined as $>55$. CTC has used "coke crush strength" as a short cut indicator of quality because the procedure to get the CSR is lengthy and costly. However, the short cut does not always correlate exactly with the CSR.

There are about 15 coke quality variables to explore to find the optimum coke. A parametric exploration of all of these variables would be costly, time consuming and also beyond the scope of work authorized by this contract. However, one of the most important for both quality and economics is the binder coal. Three tests were done with the same conditions varying only the binder coal. Knox Creek binder coal gave a crush strength of 2045 pounds. Lower Phillips binder coal gave a crush strength of 1480 pounds. Pocahontas binder coal has a crush strength of 1145 pounds. From this great variance it is clear that the binder coal is crucial to the coke quality.

Hot briquetting was also studied at some length. Briefly, hot briquetting is briquetting at a temperature where the coal is in the plastic zone (about $850^{\circ} \mathrm{F}$ ). This technique has promise because it should reduce or even eliminate the more expensive bitumen binders. A number (10) of hot briquetting tests were made with the conclusion that hot briquetting does not look attractive at this time, This test work showed that the hot briquetting produces a coke with about half the crush strength of cold briquetting using the equipment and process techniques available at the time. With the equipment available, hot briquetting is a more difficult technique where fumes and fire can pose problems. One test caught fire. This factor and other disadvantages eliminate the hot briquetting from further consideration in this current program. It is still reasoned that hot briquetting could produce coke of equal quality as cold briquetting but it would take a carefully designed Pilot Demonstration Unit and extensive test work which are beyond the scope of this project.

Chars from the Batch Mild Gasification Unit were compared to chars from the Continuous Mild Gasification Unit as they contribute to coke quality. The first basic premise was to compare the two charmaking technologies as they apply to coke. As close as possible all the other variables were held constant. Of course the same raw materials were used. All process variables were held constant. In this test matrix it was determined that char from either manufacturing technique was equal quality for the production of coke. 
Several types of furnaces were studied both on paper and with testing as well as evaluated economically. On January 10, 1991, briquettes coked in a Hankin-Nichols Multiple Hearth Furnace were evaluated. This furnace is interesting in concept; however the results of this test were poor, The test as performed did not simulate a commercial furnace well,

Another candidate for the continuous calciner is Kennedy Van Saun Company, a designer and manufacturer of 17 large scale petroleum coke calcining plants that have been installed around the world. In a proposed 2000 tons per day plant they recommend two parallel calcining lines each with a rotary tube kiln calciner 13 feet diameter $x$ 285 feet long. The volatile gas driven off the coke on the two lines could producean estimated 1,070,000 pounds per hour of steam or enough to generate 90-100 MW of electricity. Their budget price for the calcining equipment without the waste heat boiler or power generation equipment is $\$ 31,865,000$ and $\$ 21,000,000$ for installation. We did not ask Kennedy Van Saun for the price of a 1000 pounds per hour calciner.

Another candidate to supply a calciner is American Gas Furnace, Inc. They have diligently worked with CTC for nine months. Their last and best proposal for a 1000 pounds per hour calciner was $\$ 107,120$ which included much of the installation cost. We were concerned with two problems: (1) Can the product run 18 inches deep and will quality be consistent at this load depth; (2) With briquettes tumbling for one hour at $2000^{\circ} \mathrm{F}$, how much product degradation will there be. Probably those questions could have been answered by installing their proposed 36 inches $\times 20$ feet continuous calciner.

A strong candidate for the continuous calciner was offered by Salem Furnace Company. A large scale continuous calciner had been installed on a Korean project, but no operation data were yet available. Salem had quoted a price of $\$ 1,200,000$ for a 12 feet diameter rotary hearth calciner (the same type as used in Korea) for a capacity of 1000 pounds per hour of briquettes and an installed price of $\$ 9,628,000$ for a 1000 ton per day calciner and quencher system.

Fifteen hundred pounds of green briquettes were made for coking tests to be done at ABB Raymond in July. There were two runs made in a 1.25 feet diameter $x 12$ feet long direct fired rotary kiln and one run in a 6-1/2 inches diameter $x 11$ feet long indirect fired electric calciner. The tests were successful to the extent that they permitted ABB Raymond to quote equipment that would meet our needs. It must be noted that while the briquettes held together in the heating zone, there was 50 percent breakage in the cooling zone. It was felt that the breakage could be greatly reduced by varying the raw material recipe and the heat profile, After this process is refined, the breakage and abrasion probably would still result in a 20 percent loss. ABB Raymond quoted a price of $\$ 750,000$ plus or minus 15 percent for a Bartlett Snow 48 inches diameter $\times 30$ feet long indirect fired rotary calciner. This unit would heat 1000 pounds per hour of green briquettes from 60 " $\mathrm{F}$ to $1800^{\circ} \mathrm{F}$. Of various types of calciners that have been considered, 
this was the first where we have had reasonably successful tests backed up with a quoted price. However, this still did not give complete assurances that would be necessary for a commercial plant,

1992:

Batch coke formulation continued to be made and evaluated. Various raw materials and process refinements were evaluated to see the effects on the coke product. By the end of the year, a total of 150 formulations and process variables had been studied. Work focused on the type and characteristics of the char's parent coal and how the char volatile content affects the coke quality, along with the amount and type of binder coal used, and the amount and type of tar and pitch binder, In general, it was found that a char volatile content of from eight percent to 14 percent is desired for the briquetting operation depending on the characteristics of the parent coal.

The petroleum and coal tar bitumens were compared to see how they could be manipulated to get the optimum quality and economics. Hard coal tar pitch such as Allied $110 \mathrm{C}$ pitch is about $\$ 300$ per ton and asphalt such as Shell AC 20 is $\$ 140$ per ton. These prices constantly vary, but the price of asphalt is about half the price of coal tar pitch, Five tests were made with five different binders to analyze how different binders vary the coke product. The control material was held as constant as possible and was maintained at 99 percent by weight. The following bituminous binders were used in a 10 percent ratio:

Binder

150 C Allied Coal Tar Pitch

110 C Allied Coal Tar Pitch

Lion 6/9 Pen Asphalt Pitch

Shell AC 20 Road Asphalt

Roofing Tar, Asphalt Base
Crush Strength

2350

2050

2290

2100

2120

The crush strength is typical of our better briquette runs. These tests indicate that many different binders can be used to produce quality coke including asphalt pitch.

It is important to note that the control material included five percent CMGU coal tar pitch, The last three tests were petroleum products. They were compatible with coal tar pitch in this application. Hence, they can be used to supply any deficiencies of pitch production in any installation employing coals having insufficient volatile matter to furnish enough pitch binders for coking all of the char produced.

An important step taken in 1992 was the design and installation of the Coke Reactivity and Strength After Reaction Test Furnace. This test device allowed CTC to get an accurate measure of coke quality for internal use as well as an approved test to give 
potential customers and partners a solid quality test. At the time this was a Japanese test but was later adopted by ASTM. The equipment shakedown was completed in mid1992. Operation parameters were refined to achieve the greatest accuracy and repeatability $y$, The first reaction vessel made out of 316 stainless steel had a very short life of about eight tests. It was replaced with a vessel made of a Haynes HR-160 alloy with an operating temperature up to $2300^{\circ} \mathrm{F}$. That vessel has had probably 30 tests with very little deterioration. This test equipment is state of the art, totally automated, and requires no operator decisions.

Coke made on March 24, 1992, produced the best coke briquettes of the entire series. The coke had a CRI of 30.4 and a CSR of 67.0, The test results, as reported by a third party, UEC/USX Engineers \& Consultants, located in Pittsburgh, Pennsylvania, are in the Appendix, Table 5.

This data removed any risk that very good coke could be made with the CTC/DOE coking technology, and that it can be done on a commercial scale,

Work in 1992 continued to fine tune the variables that control the economics and quality. There are permutations of raw materials, heating profile, and process enhancements that require further testing to obtain the optimum coke product at the lowest cost.

The coal tar produced as a part of the coal liquids in the CTC/DOE process is an excellent binder for briquetting. The quantity of coal tar from the process may not meet the required amount. Equivalent purchased coal tar is marketed at about $\$ 300$ per ton so use of the CMGU coal tar enhances the profitability of the process.

Most of the coking done in 1992 was in an effort to improve economics and use less expensive raw materials. Ten of the coke tests were made with a cheaper, poorly coking coal with a free swelling index of $2-3$. The best coke in this test series had a crushing strength of about two-thirds of the best coke made with coking coal. It is expected that there will be interest in coke made from a non-coking coal at a somewhat reduced price; therefore this testing could be expanded,

Three hundred pounds of formed coke were produced from Penelec filter cake for evaluation. The filter cake had 44.22 percent moisture. This filter cake was dried to less than four percent moisture, loaded into the continuous mild gasification unit and made into char with the following proximate analysis: 


\section{As Received $\quad$ Dry Basis}

$\begin{array}{lrc}\text { \% Moisture } & 0,80 & - \\ \text { \% Ash } & 12.56 & 12.66 \\ \text { \% Volatile } & 5.68 & 5.73 \\ \text { \% Fixed Carbon } & \frac{80.96}{100,00} & \frac{81.61}{100.00}\end{array}$

The char was then made into formed coke using the ration of 90 percent char and 10 percent CMGU tar. This formed coke had a crush strength of 3000 pounds which is excellent. The reactivity of this coke was fair having a CRI of 43.5. The relatively high ash probably contributed to a little higher reactivity. It is felt the reactivity could be greatly improved by analyzing various different recipes and ratios of the raw materials, specifically, by adding a portion of binder coal.

Ten test runs were done with a Consolidation Coal Company poorly coking (less costly) coal. This coal has an FSI of two-three and therefore is not desirable for use as a coking coal in conventional coke ovens, The better coke made from these 10 tests has a crush strength of about two-thirds of the best coke made from coking coal.

If there is interest shown for coke made from non-coking coal at a somewhat reduced price, this testing could be expanded to improve the product from this preliminary testing, Coke made from non-coking parent coal would be used in relatively low percentages in the blast furnace,

With an extended test program using "strength after reaction" as the quality measure, the coke product could be optimized. However, coke made from lower rank parent coal will not equal coke made from" higher rank parent coal.

Work was done on how variations in the heat profile affects the quality of the coke, and what heat profile would allow for the most throughput in a specified furnace. A soak at $850^{\circ} \mathrm{F}$ was tested with very promising results. Results of coke with and without this cure are as follows:

\section{Crush Strength $\quad$ Volatile Matter}

$\begin{array}{lll}1-1 / 2 \mathrm{Hr} \text { Coke at } 1832^{\circ} \mathrm{F} & 1500 \mathrm{lbs} & 4.76 \\ 1 \mathrm{Hr} \text { Soak at } 850 \mathrm{~F}^{\prime \prime} \text { and } & 2772 \mathrm{lbs} & 0.72 \\ 1-1 / 2 \mathrm{Hr} \text { Coke at } 1832^{\circ} \mathrm{F} & & \end{array}$

To drop the volatile matter to one-fifth and increase the strength by 80 percent is a major accomplishment. The first impression would be that adding a soak at $850^{\circ} \mathrm{F}$ would 
lengthen the total heat history of the coke, However, because the volatile matter comes off so much faster while the coal is in the plastic zone, the total heat history will be shortened. The rapidly heated green briquette apparently makes a shell which restrains the volatiles.

From testing at Salem Furnace, ABB Raymond and Hanken, Inc., it has been known that briquettes containing swelling coal of 15 percent or more cannot be introduced into a coke oven at temperature. The briquette makes a hard surface or shell and the following coal contraction and swelling cause the briquette to self-destruct. This curing will eliminate that problem.

The rapid volatile loss of coal as it passes through its plastic zone was further examined. The proximate analyzer was programmed to the ASTM moisture cycle normally. The volatile cycle was modified to ramp to its final $950^{\circ} \mathrm{C}$ temperature at $10^{\circ} \mathrm{C}$ per minute. The weight loss versus temperature is shown in the Appendix, Figure 5.

In the 10 minutes ramping from $450^{\circ} \mathrm{C}$ to $550^{\circ} \mathrm{C}$, the coal lost nine percent of its total weight due to volatile loss which is more than twice the loss in any other 10 minute period as shown in the Appendix, Figure 6.

1993:

Through the entire life of this project fine tuning the variables continued, By the end of 1993, 172 different coke tests had been made. The CMGU unit was operated over a wide range of conditions within the parameters described earlier to produce char with the characteristics required for the best coke product.

A project was embarked on with a large utility, Penelec, to upgrade their 28 mesh $x$ 100 mesh coal fines using CTC technology. For this project Penelec supported CTC by enlisting the expertise of one of the top coal and coke experts in the United States and the world, Ralph Gray. This support was of particular importance because it offered a very powerful tool to the project - petrographic analysis.

The fines as received contained 40 percent moisture which was reduced to less than four percent in a thermal dryer. The dried fines were then devolatilized from 25 percent volatile matter content to 8-12 percent volatile matter at over 1100 pounds per hour in the CTC reactor. This char was used to make coke briquettes for evaluation and support by Ralph Gray Services for Penelec. This evaluation included analytical and petrographic analyses of the char, binder coal, coke and tar. Results of the coke tests are shown in the Appendix, Tables 6,7, and 8. Photomicrographs of coals, char and coke are in the Appendix, Figures 7, 8, 9, and 10. To quote Mr. Gray's report, "This report... was planned with Penelec to determine an alternate use for fine size $(28 \times 100$, $0 \times 100$, and/or $O \times 28$ ) coal. This size coal contributes to a decrease in pulverizer 
throughput at utility sites. It can definitely be used to produce coke briquettes that meet the requirements of quality metallurgical grade coke."

Mr. Gray further stated "... the process tar contained $8.4 \%$ solids (wet basis).

"The fine size solids are very low in ash-forming minerals and add to the coke yield from coal tar pitches. The coarser solids contain ash-forming minerals from the coal and are an objectionable constituent of pitch.

"Your process tar sample contained very little coarse solids. . . The normal QI content of the tar is $97.5 \%$ with only $2.5 \%$ of coal carry over. Most of the particles are spherical and appear to consist of concentric layers. The fine solids which total $84.5 \%$ are 0.25 to 1.5 microns with $13 \%$ of 1.5 to 4 micron solids. The carry over solids range from 5 to 15 microns which is on the fine size for these materials.

"Your process tar should be desirable for use in producing contract pitches for the electrode industry,"

Also, Koppers Industries, a large conventional coke maker, joined CTC in a feasibility study to determine the commercial attractiveness of a 500 ton per day CTC commercial plant to take advantage of the coke shortage projected for the latter half of this decade and beyond. This study indicated excellent returns on investment for such a project. It was thought that Koppers could be an investor in new cokemaking technology and with their cokemaking expertise they might be able to contribute to the CTC technology in some way. A 70 pound sample of CTC coke sized 3 inches $x 2$ inches was sent for an ASTM D3402-81 coke stability test. The result of the stability test was 70.2. Koppers Industries then supplied enough of their proprietary "coke blend" for one test run in the CMGU which was made in February 1993, The char produced was then blended with the binder coal, also supplied by Koppers, and coal tar from the CMGU was briquette, calcined in the bench-scale oven and the coke briquettes returned to Koppers for testing. The results of this test, as shown, were excellent, actually exceeding their best conventional coke results for reactivity. The tests were done by Koppers using the Bethlehem test for the reactivity and ASTM standards for the remaining tests.

$\begin{array}{lc}\text { Volatile Matter } & 0.54 \\ \text { Fixed Carbon } & 91.48 \\ \text { Ash } & 6.98 \\ \text { Sulfur } & 0,59 \\ \text { Stability } & 65.90 \\ \text { Hardness } & 69.10 \\ \text { Reactivity } & 7.00\end{array}$


These test results are very good, in fact, better than conventional coke made from the same feed coal. A reactivity of 12 on the Bethlehem method is considered acceptable, 7.0 is excellent.

A petrographic binder coal study was completed in 1993 to help better qualify binder coals. Using the best possible binder coal is crucial to the economics of the continuous coke process as it will allow using a minimum of pitch binder which is very expensive. Five coals were used as binder in coke tests at CTC. These same five coals were sent to Coal Petrographic Associates, Inc. in Pittsburgh for petrographic study and analysis. These coals consisted of Consol-Rend Lake Mine, Maple Creek-Pittsburgh Seam, Koppers, Lady H-Sewell Seam and Pinnacle-Pocahontas No. 3 Seam. The recipe used for the coke from these binder coals was 25 percent binder coal, 65 percent char, and 10 percent tar/pitch. This recipe was chosen because it would magnify the binder coal contribution to the final coke product. The coke was made varying only the binder coal. All other variables were held as close to constant as possible. The tests done on each binder coal were proximate, Gieseler plastometer, Arnu dilatometer, free-swelling index and petrographic analysis.

The work done by Coal Petrographic Associates for CTC is displayed as follows. The proximate and sulfur analyses are shown in the Appendix, Table 9. The results of the Gieseler plastometer, Arnu dilatometer and free-swelling index tests are shown in the Appendix, Table 10. The petrographic analyses are shown in the Appendix, Table 11. The positions of the five coals, relative to isostability curves, are shown in the Appendix, Figure. 11. The coke reactivity (CRI) and strength after reaction (CSR) tests done by CTC on coke made from these binder coals are shown in the Appendix, Table 12.

Finds of the petrographic work done are presented below,

\section{Consol-Rend Lake Mine}

The Rend Lake sample had very poor rheologic properties (O ddpm, no dilation and $3.5 \mathrm{FSI})$. This coal is marginally coking, high volatile $(0.70$ percent mean-maximum reflectance) and contains an abundance of reactive coal macerals (89,6 percent). The Rend-Lake coal produces highly reactive isotropic carbon forms in coked briquettes. The Rend Lake is a poor candidate as binder coal.

\section{Maple Creek-Pittsburgh Seam}

The sample of Maple Creek coal has the best theological properties of the bituminous coals used in this study $(29,984 \mathrm{ddpm}$ and $7.5 \mathrm{FSI})$. The petrographic analysis indicates the Maple Creek sample is a fair coking, high volatile coal in rank (0.86 percent reflectance), with a moderately low total inert content (22.5 percent). Generally, coal of this rank produces granular or fine circular anisotropic carbon forms in coke. This type 
of carbon is less reactive than the carbon forms from the Rend Lake coal but more reactive than the carbon forms from the higher rank coals used in this study.

\section{Koppers Coal}

The Gieseler plastometer and Arnu dilatometer test results (4,824 ddpm and 113 percent maximum dilation) for the Koppers coal are lower than expected for this rank of coal. The sample had a good free-swelling index (7.5). The petrographic analysis of the Koppers coal indicates it should be fairly good coking, high volatile coal $(0.94$ percent reflectance), with a moderate total inert content (24.3),

\section{$\underline{\text { Ladv H-Sewell Seam }}$}

The Lady $\mathrm{H}$ sample is low in ash and sulfur contents (3.85 and 0.85 percent, respectively) and contains 28.59 percent dry, ash-free volatile matter. The sample is fairly low in fluidity $(1,174 \mathrm{ddpm})$ and dilation ( \pm 125 percent maximum dilation) and has a free-swelling index (8.5 FSI). The rheologic properties of this sample were low for coal of this rank and were significantly lower than results obtained by our laboratory on previous samples of this coal, Petrographically, the Lady $\mathrm{H}$ sample is borderline high/medium volatile coal in rank with a1.12 percent mean-maximum reflectance. In addition, the sample is relatively low in total inert content (19.9 percent).

\section{Pinnacle-Pocahontas No. 3 Seam}

The Gieseler plastometer and Arnu dilatometer test results ( 8 ddpm and 13 percent maximum dilation) are on the low side for this product. The sample has a good freeswelling index (8.0 FSI). Petrographically, the Pinnacle sample is a medium range, low volatile coal in rank ( 1.61 percent reflectance), with a moderately high total inert content (27,0 percent).

Coal Petrographic was used to characterize a wide variety of coal ranks and compositions and relate their properties to their performance as binders in the CTC coke process. Much was learned to characterize binder coal from the petrographic approach. Coal Petrographic Associates recommends that in the future mid-range coals with medium volatiles (about 1.25 percent reflectance) having a moderate inert content be obtained for testing.

In 1993 CTC has used the binder coal data along with the DOE supported Penn State Coal Sample Bank and Database to locate potential binder coal sources, This database is a powerful source in identifying coals and probably is unequaled anywhere in the world. From data supplied to Penn State over 1,130 coals were analyzed to find coals that met the required characteristics and brought the potential sources down to a manageable number. 
With available equipment, continuous coke was made which met or exceeded conventional coke laboratory specifications. To continue to move toward market acceptance, quantities of coke were needed which would allow for large scale testing of CTC coke.

Preliminary work began on an extension of this project which would construct a facility to continuously produce coke. The unique feature of this facility is that it was built with used equipment. A new rotary hearth furnace had been quoted at $\$ 1.3$ million. If the furnace cost is half the total equipment cost, the total equipment cost would then be $\$ 2.6$ million. Also, if the equipment cost is half the total construction cost, that would put the construction cost of a facility with new equipment at $\$ 5.2$ million. By constructing the facility with used equipment, the total equipment cost was approximately $\$ 300,000$. With modifications to equipment, installation, and shakedown, the total project was built for approximately $\$ 850,000$ which was a major savings of government and DOE funds.

This extension was titled, Task 5. Continuous Briquetting and Coking. Work was covered under Task 5.

1994:

Most work was focused on building the PDU to make continuous coke in quantities to test in a cupola, Some work continued on a bench-scale in areas that had merit. One test was done with the single objective of doing well on the reactivity (CRI) and strength after reaction (CSR) which was achieved. This coke had a CSR of 74.7 and a CRI of 23.5. A summary is in the Appendix, Table 13, showing the various coals used to make metallurgical grade coke on this project. These 12 different coals illustrate the versatility of the CTC coking technology.

\section{TASK 4. PDU DESIGN}

In September 1987, UCC Research Corporation later to become Coal Technology Corporation, entered into a contract with the U.S. Department of Energy to develop a continuous coal mild gasification process under Contract Number DE-AC21-87MC241 16: (1) A literature survey and market assessment was done as Task 1; (2) A bench-scale mild gasification study was completed as Task 2; and (3) A bench-scale char coking study was made as Task 3 . After completion of these three tasks, a recommendation was made to design and build a $1000 \mathrm{lb} . / \mathrm{hr}$. screw-type mild coal gasification process demonstration unit (PDU). Task 4a. and Task 4.b. were added to the original contract to design and build the PDU, respectively.

The initial design concept was a single screw reactor. Plugging of bench-scale single screw reactors and a need for increased heat transfer rate resulted in a design change to a double screw reactor. Christian Engineering of San Francisco, California, designed 
and fabricated the twin screw reactor, The reactor consists of a pair of 16 feet long by 16 inch diameter interfolded screws inside a housing. The cross section of the screw housing is in the shape of an inverted heart to provide an open space above the screws to allow for expansion of the coal as it becomes plastic and to provide for passage of the vaporized gases from the reactor. The housing is heated on the bottom by two zones of radiant gas burners. The zones are 3 feet long at the coal feed end and 13 feet long to the char discharge end. Each burner zone is controlled separately. The burners and reactor are enclosed by a shell to direct the combustion gases around the reactor housing and out through a top centrally located exhaust port into a flue that extends to the top of the building. The screw housing and furnace are surrounded by an insulated shell. The screws are fabricated using 10-inch pipes as stem pipes, The original design had full length calrod heaters inside the screws. The calrod heaters proved to be unreliable and replacement with gas fired heaters will be discussed later in this report. The screws' hydraulic drive original reduction ratio provided for a screws' rotation rate of 17 RPM. The drive system is reversible and forward - reverse ratios can be selected to control residence time in the reactor. The drive system also included a "Lost Motion Clutch" which provides for one screw to lag the other about 30 degrees in rotation when rotation direction is changed. This causes the flights of one screw to move between the flights of the other screw and acts as a clearing action to help prevent caking of the screws.

Christian Engineering also supplied the char cooler. The cooler is a standard Holoflight $\circledast$ screw conveyer which cools the char from the screw reactor indirectly with water flowing through the hollow screw and the conveyer jacket.

Production Industries Corporation (PICOR) of Johnson City, Tennessee, provided the engineering services for the PDU installation. The tanks, bins, and other metal fabrication were done by Allied Metals Company also of Johnson City, Tennessee, as specified by PICOR.DB Enterprises of Johnson City, Tennessee, was the instrument engineering company for the PDU. Controls for the gas fired radiant heaters were included with the heaters from Red Ray Corporation of Boston, Massachusetts. Details of the screw reactor are shown in the cross section on the following page.

\section{PDU Construction/Shakedown}

Trade Master Contracting of Naples, North Carolina, built the PDU at CTC's site in Bristol, Virginia. The PDU includes a five-story building housing the screw reactor and auxiliary equipment and a single story building for offices, The char storage bin is also located in the single story building which also included space for future coke production using the char,

Construction started in August of 1990, The only major construction problem encountered was the late shipment of the screw reactor. Construction plans called for 
the screw reactor to be set early in the building erection and the building completed with the screw reactor in place. This construction delay was minimized by continuing with the project but leaving an opening in the building that would permit later installation of the screw reactor. Construction was completed in February 1991.

Equipment testing before start-up uncovered only a few problems. The natural gas pressure regulator for the radiant gas burners was undersized and was replaced by the gas company. The hydraulic power unit included a "power saver" on the supply pump which did not work as claimed and caused overheating of the hydraulic oil. The "power saver" device was removed. Also the radiant gas burners required adjustments to provide precise temperature control. As a final check, the screw reactor system was tested in a dry run to insure that all components operated as designed.

The following cross sections show the details of the screw reactor design.

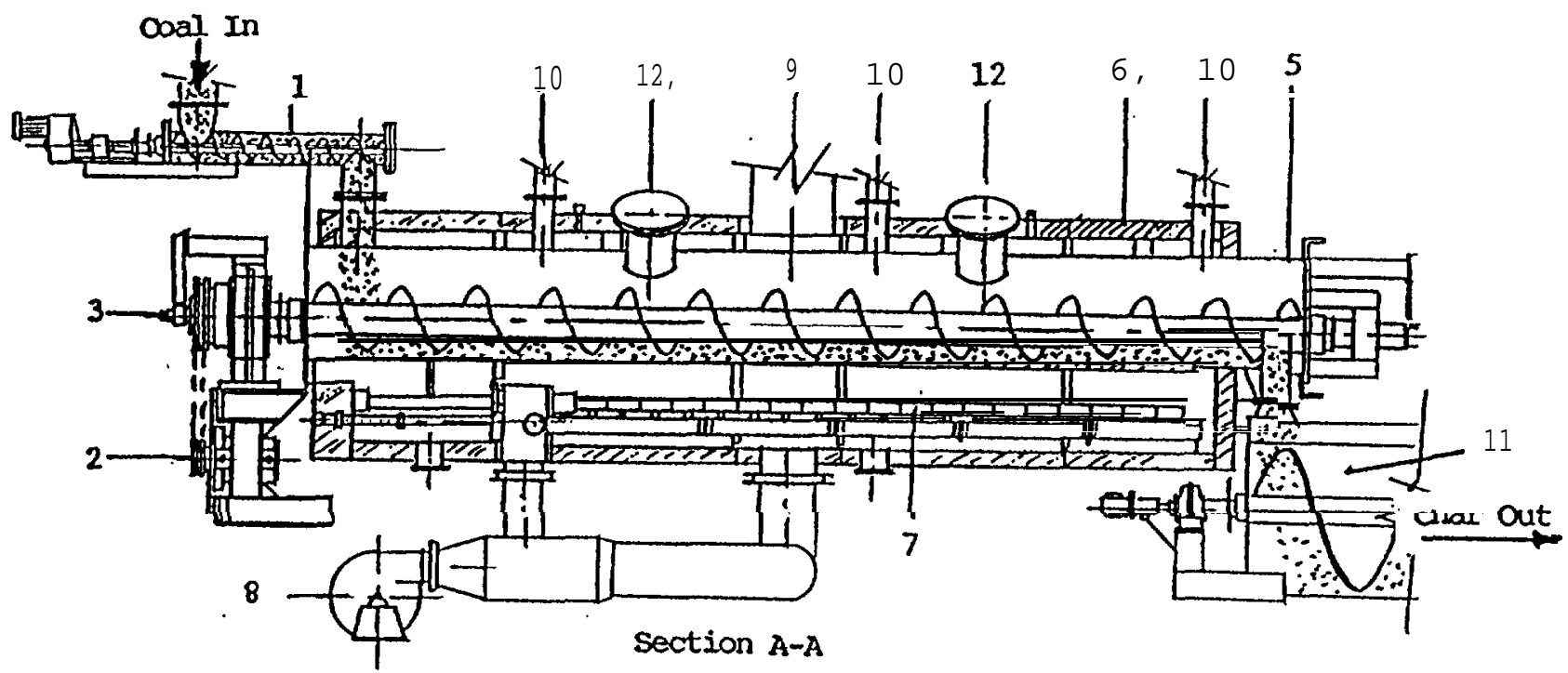

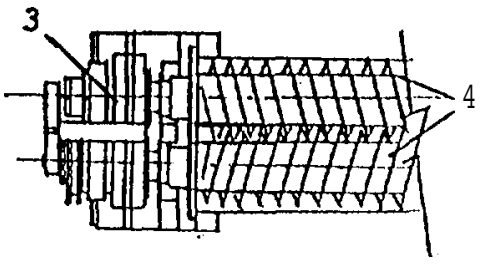

Section C-C

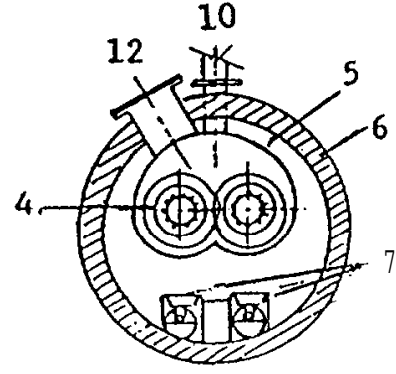

section $\mathrm{B}-\mathrm{B}$

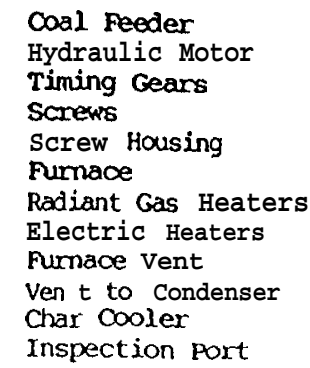

Inspection port

Process Description

As-received coal is dried to less than three percent moisture and pulverized to minus 1/4-inch mesh through a hammer mill which discharges into the coal weigh bin, 
The screw reactor is preheated to $1200^{\circ} \mathrm{F}$ to $1400^{\circ} \mathrm{F}$ while purging the system with nitrogen to eliminate oxygen. The screws are rotating at a preset forward/reverse ratio while preheating. Coal feed is started through a variable speed screw conveyer into the top feed end of the screw reactor. The coal is heated to the plastic state, $700^{\circ} \mathrm{F}$ to $800^{\circ} \mathrm{F}$ and pyrolysis of the coal starts with the generation of volatiles. The volatiles flow to a condenser system where tars, heavy oils and light oils condense and are collected in a storage tank. Non-condensable gases containing about 50 percent methane, 40 percent hydrogen and a 10 percent mixture of low molecular weight hydrocarbons, carbon monoxide and carbon dioxide along with traces of hydrogen sulfide and sulfur dioxide are flared. In a commercial plant the non-condensable gases will be used as process fuel. The reactor internal pressure is in the range of two to five inches of water. As pyrolysis progresses, a solid product, char, is formed which contains up to 80 percent fixed carbon. Char yield is about 70 percent of the coal feed. Char can be considered as "semi coke." The char has a bulk density of 29 pounds per cubic foot and is in irregular shaped particles up to 1-1/2 inch mesh. The particles are quite porous from the action of evolving volatiles and are friable. Fines present in the char are largely due to mechanical action of the screws as the char is conveyed down the screw reactor. Based on experience, when pyrolyzing a good metallurgical caking coal, the coal preheat zone to the plastic state is about three feet long starting at the feed end of the screw reactor. The coal becomes plastic in the range of $700^{\circ} \mathrm{F}$ to $800^{\circ} \mathrm{F}$ and the plastic zone is about five feet long, In this plastic zone most of the volatiles removal takes place forming char. The free flowing char is conveyed down the remaining eight feet length of the screw reactor with the char temperature rising to 1000 "F to 1100 "F when discharged to the char cooler. Low molecular weight volatiles are removed from the char at the higher temperatures, including methane and hydrogen.

\section{$\underline{\text { PDU Start-Up }}$}

Shakedown runs were started in January 1991. Coal feed rates of up to 750 pounds per hour for short durations indicated that the twin screw design would process coking coals. Several problems were incurred in the first few months of operation which are discussed in the following paragraphs.

\section{Electric Heaters}

The screw reactor was originally fitted with internal $65 \mathrm{KW}$ calrod heaters in each screw, Since the screws including the area of the flights provide about 75 percent of the effective heat transfer area, internal heating of the screws is critical. These heaters were mounted on five inch stainless steel support pipes which were inserted into the 10 inch diameter stem pipes. Supports at each end of the five inch support pipes allowed the heaters to be stationary.

Clearances between the rotating screws and electrical connections inside the stem pipes were not great enough to prevent shorting of the heaters. The screws were not 
completely straight which added to the low clearances problem. Attempts were made to repair the heaters, but they could not be made reliable enough to evaluate the screw reactor as designed. After the electric heaters were replaced with natural gas fired pulse burners, and other problems solved as discussed later, prolonged test runs at 1000 pounds per hour coal feed were possible.

\section{Hydraulic Drive System}

The original screws' hydraulic drive system was 25 horsepower with a newly developed "power saver" feature on the hydraulic pump, In the early test runs the drive system overloaded and the hydraulic oil over-heated. The manufacturer attempted to correct the problem without success. It was recommended to remove the "power saver" unit. Drive overloads continued. It was understood that the absence of the screws' internal heaters was a major factor in the drive problem. The 25 horsepower electric motor was replaced with a 30 horsepower electric motor and finally with a 40 horsepower electric motor. The hydraulic drive motor mounted on the screw reactor was not performing to design specifications and it was returned to the manufacturer for repairs, With the 40 horsepower electric motor and the repaired hydraulic motor, the screws still slowed to unacceptable speed with coal feeds below 500 pounds per hour. The test runs were limited to three to four hours,

The replacement system for heating the screws internally was on order but had not been received.

\section{Screw Cracking Problems}

One of the two screws developed a crack on May 18, 1992. Over a period of two months, the same screw cracked five times. It is believed that the welding for this screw was not done properly. Cracks were usually in a weld area, but not always, and all cracks occurred in the same section of the screw. The screws were fabricated using 10 inch 304 stainless steel schedule 40 ( 0.365 wall thickness) stem pipes. Alloy 304 is not considered a good high temperature material. The screws were replaced with ones using 10 inch 310 stainless steel schedule 60 (0.500 wall thickness) stem pipes. Correct welding methods were used. No additional screw failures have occurred,

\section{Screws' Housing Cracking Problem}

On May 11, 1991, a weld failure in the bottom of the screws' housing caused a process leak. Poor weld penetration was determined to be the cause. Problems with the original screws also caused other damage to the screws' housing when they rubbed against the housing, Sections of plate were welded over the worn areas. 


\section{Condenser Problems}

Theoriginal condenser system wasthree cascade condenser boxes. Coal liquids were charged to the boxes prior to operation of the screw reactor. A pump on each box circulated the liquid from the bottom onto a series of three sloping plates. The vapors from the screw reactor entered at the bottom and contact between vapor and liquid condensed coal liquids in the box which overflowed to a weigh tank.

The basic design of the condensers did not provide good contact between vapors and liquids. Channeling of both liquids and vapors to some degree occurred. Solids and tars that carried over from the screw reactor plugged the condensers. The complicated systems of plates and baffles inside the condensers prevented clearing of plugs. Efforts were made to improve the condensers including: (1) installation of sloping bottoms to increase tar and solids capacity; (2) addition of strip heaters to melt tars and prevent the condensation of water; (3) installation of a large electric heater on one condenser; and (4) insulation of vapor lines to prevent condensation of tars. After only limited success in improving the condensers, it was decided to replace them with a single condenser.

\section{Screw Reactor Operations}

The period of screw reactor operation prior to installation of the natural gas fired pulse burners was beneficial but also frustrating. Knowledge was gained about the process and equipment which resulted in process improvements and corrections of equipment flaws. Experience working with plastic coal, replacement of the original screws, hydraulic drive improvements, and the basis for a new condenser design were highlights of this period, The frustration came from not being able to run the screw reactor even near the design capacity of 1000 pounds of coal feed per hour. Since internal heating of the screws is critical to the operation of the screw reactor, performance without screws' heating is of little interest. The following table shows the results of test runs made just prior to installation of the pulse burners to heat the screws. These test runs include the culmination of knowledge and experience gained in operation of the screw reactor with unheated screws, 
CMGU TEST RUNS WITHOUT SCREW HEATERS

\begin{tabular}{|c|c|c|c|c|c|c|c|c|c|}
\hline $\begin{array}{l}\text { Run } \\
\text { No. }\end{array}$ & $\begin{array}{l}\text { Run } \\
\text { Length } \\
\text { Hours }\end{array}$ & $\begin{array}{l}\text { Fuel } \\
\text { Ratio }\end{array}$ & $\begin{array}{l}\text { Residence } \\
\text { Time } \\
\text { Minutes }\end{array}$ & $\begin{array}{l}\text { Forward } \\
\text { Reverse } \\
\text { Ratio }\end{array}$ & $\begin{array}{l}\text { Char } \\
\text { Volatiles } \\
\%\end{array}$ & $\begin{array}{l}\text { Char } \\
\text { Fixed } \\
\text { Carbon } \\
\%\end{array}$ & $\begin{array}{l}\text { Coal } \\
\text { Liquid } \\
\text { Yield } \\
\%\end{array}$ & $\begin{array}{l}\text { Char } \\
\text { Yield } \\
\%\end{array}$ & $\begin{array}{l}\text { Feedrate } \\
\text { Lb./Hr. }\end{array}$ \\
\hline 28 & $4: 00$ & 12.1 & 2.53 & $60 \mathrm{~F} / 9 \mathrm{~A}$ & 7.14 & 86.48 & 7.0 & 64.4 & 548 \\
\hline 30 & $3: 00$ & 10.7 & 4.93 & $20 \mathrm{~F} / 9 \mathrm{R}$ & 8.00 & 85.65 & 11.9 & 73.5 & 600 \\
\hline 31 & $3: 00$ & 12.3 & 2.73 & $49 \mathrm{~F} / 9 \mathrm{R}$ & 7.05 & 86.42 & 2.8 & 78.0 & 296 \\
\hline 32 & $3: 00$ & 14,9 & 5.22 & $39 F / 19 R$ & 5.87 & 86.67 & 2.7 & 51.0 & 300 \\
\hline 33 & $3: 00$ & 20.0 & 7.48 & $35.7 F / 22.3 R$ & 4.49 & 89.92 & 2.0 & 49.7 & 288 \\
\hline 34 & $3: 00$ & 22.4 & 9.63 & $34 \mathrm{~F} / 24 \mathrm{R}$ & 3.99 & 89.32 & 15.1 & 61.9 & 320 \\
\hline 35 & $3: 00$ & 20.6 & 7.43 & $17.4 \mathrm{~F} / 10 \mathrm{R}$ & 4.30 & 88.50 & 5.1 & 39.2 & 293 \\
\hline 36 & $2: 30$ & 21.0 & 7.61 & $23.4 \mathrm{~F} / 14 \mathrm{R}$ & 4.20 & 88,40 & 5.8 & 50.2 & 315 \\
\hline
\end{tabular}

New screws were installed on August 31, 1992. The screws were fitted with "flow control tubes" as part of the pulse burners. These eight-inch diameter tubes extend within a foot of each end of the screws and are centered in the screws. The one-inch annulus in each screw provides high velocity flow of the pulse burners' combustion gases to increase the heat transfer rate to the inside walls of the screw. The screws' flights are continuously welded to the stem pipes and are also heated by the combustion gases.

The pulse burners burn natural gas. Air is supplied up to 50 inches of water. At a given gas supply pressure up to $10 \mathrm{psig}$, air pressure is adjusted until the burners operate with a steady flame. Each burner is rated for a maximum of 300,000 Btu/hour. Combustion gases flow counter currently to the process stream and are exhausted at the feed end of the screw reactor to the main stack.

Problems with feeding as received coal to the screw reactor was a re-occurring problem since the start of operations. Coal above three percent moisture bridged in the coal weigh bin and often limited the coal feedrate and caused uneven feed rates. Asreceived coal moisture ranged from five percent to 10 percent. A coal dryer was fabricated using an available 20 feet long, six inch diameter screw conveyor and a 4 foot $x 4$ foot hopper, The screw was installed to convey from the hopper to the coal bucket conveyor receiving bin. Pipe type natural gas burners were installed below the screw conveyor to heat the first 10 feet of the screw from the hopper. The screw conveyor is inclined about 45 degrees, Heat transfer to the dryer was improved by covering the top half of the screw housing with a two-inch thick layer of stainless steel machine turnings. The turnings are held in place with stainless steel sheet metal. A sheet metal jacked encloses the burners and screw. The burners heat the bottom of the screw housing directly. The combustion gases flow into the machine turnings and heat the top of the 
screw housing, The top section of the screw housing is also covered with machine turnings and the combustion gases flow through these turnings to the stack. The dryer will dry coal at eight percent moisture to 2,8 percent moisture at a rate of 700 pounds per hour coal feed, Initial attempts to dry coal without the machine turnings heat transfer improvement failed. Dried coal discharged to the coal receiving bin is moved to the screw reactor coal weigh bin by the bucket elevator. The coal weigh bin will hold 6,000 pounds.

With the new screws and pulse burners installed and coal feed problems solved, operations of the screw reactor as originally designed started. The first test run, 37-92, with the pulse burners had a 700 pounds of coal per hour feedrate. The run was of short duration but no hydraulic drive problem occurred. The run was stopped because the star valve coal feeder jammed, The second test run, 38-92, with the pulse burners was at a rate of 900 pounds coal per hour feed and was continued until the coal weigh bin emptied. The char from this run contained 10 percent to 12 percent volatiles.

The coal used in test runs after installation of the new screws and pulse burners was Red Ash Coal from Pocahontas Land Company which is a mid-volatile coal at 24 percent to 26 percent volatiles. After the new screws-pulse burners check out runs, an extended run at a high feedrate was attempted as test run 42-92 using this PLC coal. After four hours at a coal feedrate of 700 pounds per hour, problems with the coal conveyer screw occurred, Before the problem could be corrected, one of the pulse burners overheated and shutdown. The importance of the pulse burners was dramatically shown when high hydraulic drive pressure required that the coal feed be decreased to 300 pounds per hour to continue the run. After test run 42-92, the pulse burner that had overheated was inspected and no damage had occurred.

Test runs were continued with different coals in the remainder of 1992 and in 1993. Determination of the optimum forward/reverse ratio was a major objective of these test runs. It was found that since plastic coal does not follow screw conveyor mechanics, the forward/reverse ratio was ineffective as measured by the char volatile contents when running the same coals at equal feedrates. Running the screw reactor at full forward produced char with 10-12 percent volatiles. These test runs and laboratory experiments also showed that volatiles are difficult to remove from char. Char heated to $1600^{\circ} \mathrm{F}$ in a muff le furnace dropped only three percent in volatiles from 15 percent. The volatiles in char from most coals processed were below 12 percent when running the screw reactor at or near capacity. Since good formed coke can be made from char at 10 percent to 12 percent volatiles, a production sized screw reactor with a forward only capability will be more durable and cost less. The results of 35 test runs are shown in on the following page,

With the higher coal feedrates made possible by the pulse burners, problems with the condensers reappeared. The three relatively small four inch diameter vapor outlets and the 3.5 feet long vapor lines plugged frequently. Tar and solid particles accumulated in 
these lines and were the cause of some test run shutdowns. The condenser bottoms also filled with tar and were hard to drain. Efforts including (1) heating the vapor lines with electric heaters; (2) insulating the lines; and (3) using high pressure nitrogen "blasts" did not solve the problem. 
SUMMARY OF CMGU TESTS (1993)

\begin{tabular}{|c|c|c|c|c|c|c|c|c|c|c|c|c|c|}
\hline $\begin{array}{l}\text { Run } \\
\text { No, }\end{array}$ & $\begin{array}{l}\text { Date \& } \\
\text { Hrs/Min } \\
\text { Duration }\end{array}$ & $\begin{array}{l}\text { Coal } \\
\text { Used }\end{array}$ & $\begin{array}{l}\text { Coal } \\
\text { Feedrate } \\
\text { Lb/Hr }\end{array}$ & $\begin{array}{l}\text { Forward } \\
\text { Reverse } \\
\text { Ratio }\end{array}$ & $\begin{array}{l}\text { Zone } \\
\# 2 \\
{ }^{\circ} \mathrm{F}\end{array}$ & $\begin{array}{l}\text { Liquid } \\
\mathrm{Lb} / \mathrm{Hr}\end{array}$ & $\begin{array}{l}\text { Char } \\
\% \\
\text { Volatile } \\
\text { Avg, }\end{array}$ & $\begin{array}{l}\text { Char } \\
\% \\
\text { Ash } \\
\text { Avg. }\end{array}$ & $\begin{array}{l}\text { Char } \\
\% \\
\text { F.C. } \\
\text { Avg. }\end{array}$ & $\begin{array}{l}\text { Char } \\
\mathrm{Lb} / \mathrm{Hr}\end{array}$ & $\begin{array}{l}\text { Coal } \\
\text { Liq. } \\
\%\end{array}$ & $\begin{array}{l}\text { Char } \\
\%\end{array}$ & Notes \\
\hline 01-93 & $\begin{array}{l}01 / 05 / 93 \\
3: 00\end{array}$ & Red Ash & 422 & 60FOR/10P & 1133 & 27.0 & 7.40 & 4.70 & 87.20 & 265 & 5.80 & 74.40 & \\
\hline 02-93 & $\begin{array}{l}01 / 08 / 93 \\
1: 30\end{array}$ & Penelec & 1163 & $60 \mathrm{FOR} / 10 \mathrm{P}$ & 1002 & 13.3 & 11.60 & 8.70 & 80.90 & 374 & 1.10 & 32.20 & \\
\hline 03-93 & $\begin{array}{l}02 / 16 / 93 \\
3: 30\end{array}$ & Poca \#3 & 924 & $60 \mathrm{FOR} / 10 \mathrm{P}$ & 1287 & 37.0 & 10.50 & 6.00 & 83.50 & 796 & 4.00 & 86.10 & \\
\hline 04-93 & $\begin{array}{l}02 / 18 / 93 \\
4: 30\end{array}$ & Poca \#3 & 631 & $60 \mathrm{FOR} / 10 \mathrm{P}$ & 1275 & 22.0 & 6.80 & 6.20 & 87.00 & 536 & 3.40 & 84.90 & \\
\hline 05-93 & $\begin{array}{l}02 / 22 / 93 \\
4: 10\end{array}$ & $\begin{array}{l}\text { Koppers } \\
\text { Coal } \\
\text { Blend }\end{array}$ & 629 & SOFORIOP & 1297 & 46.0 & 8.50 & 7.80 & 83.70 & 456 & 7.30 & 72.50 & \\
\hline 06-93 & $\begin{array}{l}02 / 25 / 93 \\
3: 50\end{array}$ & Poca \#3 & 654 & $60 \mathrm{FOR} / \mathrm{OP}$ & 1324 & 20.0 & 7.30 & 6.10 & 86.70 & 539 & 4.00 & 82.50 & \\
\hline $07-93$ & 03/02/93 E) & PERIMENTA & RUN USING & PENELEC CH & AS FEE & & & & & & & & \\
\hline 08-93 & $\begin{array}{l}\text { 03/22/93 } \\
18: 00\end{array}$ & Poca \#3 & 480 & $60 \mathrm{FOR} / 1 \mathrm{P}$ & 1279 & 24.4 & 7.70 & 5.70 & 86.30 & 343 & 2.40 & 75.60 & \\
\hline 09-93 & $\begin{array}{l}\text { 04/07/93 } \\
5: 30\end{array}$ & Poca \#3 & 680 & $\begin{array}{l}\text { Full } \\
\text { Forward }\end{array}$ & 1362 & 52.0 & 8.42 & 5.43 & 86.15 & 597 & 4.90 & 87.80 & (1) \\
\hline $10-93$ & $\begin{array}{l}04 / 14 / 93 \\
4: 30\end{array}$ & Poca \#3 & 452 & $\begin{array}{l}\text { Full } \\
\text { Forward }\end{array}$ & 1176 & 8.7 & 9.79 & 5.68 & 84.53 & $\mathrm{~N} / \mathrm{A}$ & 1.90 & $N / A$ & (1) \\
\hline $11-93$ & $\begin{array}{l}04 / 19 / 93 \\
4: 30\end{array}$ & Poca \#3 & 1183 & $\begin{array}{l}\text { Full } \\
\text { Forward }\end{array}$ & 1342 & 44.0 & 10.19 & 5.86 & 83.95 & 938 & 4.00 & 85.80 & (2) \\
\hline $12-93$ & $\begin{array}{l}04 / 24 / 93 \\
5: 00\end{array}$ & Poca \#3 & 838 & $\begin{array}{l}\text { Full } \\
\text { Forward }\end{array}$ & 1213 & 18.0 & 9.55 & 6.11 & 84.42 & 702 & 2.20 & 86.51 & (1) \\
\hline 13-93 & $\begin{array}{l}\text { 04/28/93 } \\
5: 00\end{array}$ & Poca \#3 & 831 & $\begin{array}{l}\text { Full } \\
\text { Forward }\end{array}$ & 1220 & 16.0 & 9.01 & 6.17 & 84.82 & 736 & 1.90 & 88.51 & (1) \\
\hline $14-93$ & $\begin{array}{l}05 / 03 / 93 \\
6: 00(1)\end{array}$ & Poca \#3 & 633 & $\begin{array}{l}\text { Full } \\
\text { Forward }\end{array}$ & 1171 & 34.0 & 9.00 & 4.89 & 86.12 & $N / A$ & 5.38 & $N / A$ & 2072 \\
\hline $15-93$ & $\begin{array}{l}05 / 12 / 93 \\
1: 45(1)\end{array}$ & Poca \#3 & 563 & $\begin{array}{l}\text { Full } \\
\text { Forward }\end{array}$ & 1303 & 47.0 & 8.25 & 4.69 & 87.33 & 488 & 8.32 & 86.70 & 1904 \\
\hline $16-93$ & $\begin{array}{l}05 / 14 / 93 \\
8: 00 \text { (1) }\end{array}$ & Poca \#3 & 958 & $\begin{array}{l}\text { Full } \\
\text { Forward }\end{array}$ & 1368 & 42.0 & 9.02 & 5.34 & 85.63 & 794 & 4.30 & 82.90 & 1754 \\
\hline $17-93$ & $\begin{array}{l}\text { 05/20/93 } \\
3: 13(1)\end{array}$ & Poca \#3 & 493 & $\begin{array}{l}\text { Full } \\
\text { Forward }\end{array}$ & 1305 & 31.0 & 8.08 & 5.52 & 86.39 & 424 & 6.33 & 86.60 & $\mathrm{~N} / \mathrm{A}$ \\
\hline $18-93$ & $\begin{array}{l}05 / 26 / 93 \\
3: 15 \text { (1) }\end{array}$ & Lady H & 726 & $\begin{array}{l}\text { Full } \\
\text { Forward }\end{array}$ & 1380 & 48.0 & 12.59 & 4.62 & 82.79 & 462 & 6.65 & 63.60 & $\mathrm{~N} / \mathrm{A}$ \\
\hline $19-93$ & $\begin{array}{l}06 / 02 / 93 \\
5: 30(1)\end{array}$ & $\begin{array}{l}\text { Lady H } \\
\text { (Sewell) }\end{array}$ & 623 & $\begin{array}{l}\text { Full } \\
\text { Forward }\end{array}$ & 1380 & 60.9 & 11.18 & 4.74 & 84.08 & 499 & 9.80 & 80.17 & 2360 \\
\hline $20-93$ & $\begin{array}{l}06 / 07 / 93 \\
2: 30 \text { (1) }\end{array}$ & Lady H & 726 & $\begin{array}{l}\text { Full } \\
\text { Forward }\end{array}$ & 1393 & 35.0 & 11.12 & 5.37 & 83.51 & 535 & 4.90 & 73.72 & 1652 \\
\hline $21-03$ & $\begin{array}{l}06 / 09 / 93 \\
3: 30(1)\end{array}$ & Lady H & 333 & (3) & 1328 & 34.0 & 8.65 & 4.91 & 86.45 & 257 & 10.20 & 77.25 & 4655 \\
\hline $22-93$ & $\begin{array}{l}06 / 21 / 93 \\
8: 00 \text { (1) }\end{array}$ & Lady H & 404 & (3) & 1288 & 32.1 & 9.13 & 4.76 & 86.12 & 299 & 8.00 & 74.12 & 3787 \\
\hline 23-93 & $\begin{array}{l}06 / 24 / 93 \\
5: 00(1)\end{array}$ & Lady H & 617 & (3) & 1356 & 43.8 & 10.23 & 4.75 & 85.02 & 464 & 7.10 & 75.27 & $\mathrm{~N} / \mathrm{A}$ \\
\hline $24-93$ & $\begin{array}{l}06 / 29 / 93 \\
2: 00(1)\end{array}$ & Lady H & 418 & (3) & 1342 & 45.0 & 9.29 & 4.85 & 85.87 & 330 & 10.70 & 79.04 & N/A \\
\hline $25-93$ & $\begin{array}{l}07 / 01 / 93 \\
8: 00 \text { (1) }\end{array}$ & Lady H & 612 & (3) & 1348 & 41.0 & 9.10 & 4.76 & 85.40 & 447 & 13.00 & 73.00 & 2773 \\
\hline $26-93$ & $\begin{array}{l}07 / 13 / 93 \\
6: 00(1)\end{array}$ & Lady $\mathrm{H}$ & 530 & (3) & 1328 & 42.0 & 8.80 & 4.81 & 85.72 & 409 & 7.60 & 62.70 & 3226 \\
\hline $27-93$ & $\begin{array}{l}07 / 20 / 93 \\
8: 00 \text { (1) }\end{array}$ & Lady H & 564 & (3) & 1297 & 28.2 & 9.10 & 4.76 & 85.38 & 400 & 1.00 & 71.00 & 2748 \\
\hline $28-93 \mathrm{~A}$ & $\begin{array}{l}08 / 02 / 93 \\
6: 00(2)\end{array}$ & Lady H & 825 & (3) & 1322 & & 10.60 & & & 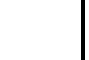 & & & N/A \\
\hline $28-93 B$ & $\begin{array}{l}08 / 02 / 93 \\
1: 30(2)\end{array}$ & Lady $\mathrm{H}$ & 1066 & (3) & 1380 & 68.2 & 10.90 & 4.64 & 84.07 & $6 / 6$ & .10 & 71.37 & 1419 \\
\hline $29-93$ & $\begin{array}{l}08 / 07 / 93 \\
4: 00\end{array}$ & Lady H & 498 & (3) & 1310 & 36.0 & 10.78 & 4.88 & 84.34 & 419 & 7.20 & 84.12 & .. \\
\hline $30-93$ & $\begin{array}{l}08 / 11 / 93 \\
4: 06\end{array}$ & Lady H & 1073 & (3) & & 89.8 & 15.31 & 4.75 & 79.94 & 8.68 & 8.40 & 80.90 & 1556 \\
\hline $31-93$ & $\begin{array}{l}08 / 13 / 93 \\
7: 20\end{array}$ & $\begin{array}{l}\text { Misc. } \\
\text { Coal \& } \\
\text { Char }\end{array}$ & 741 & (3) & & 21.6 & 11.00 & 6.61 & 83.02 & 579 & $2: 90$ & 77.83 & 2076 \\
\hline $32-93$ & $\begin{array}{l}08 / 17 / 93 \\
0: 35\end{array}$ & Peerless & & (4) & & & $V$ TERMINAT & TED DUE 7 & TO METAL & OBJECT I & IN DELUM & PER & \\
\hline $33-93$ & $\begin{array}{l}08 / 18 / 93 \\
1: 45\end{array}$ & Peerless & 314 & (4) & - & 10.4 & 8.77 & 4.40 & 86.83 & 182 & 620 & 57.06 & 4933 \\
\hline $34-93$ । & 08/20/93 & $\begin{array}{l}\text { Cedar } \\
\text { Grove }\end{array}$ & & & & & $V$ TERMINAT & TED DUE & TO ELECTF & RICAL POV & WER FAILI & URE & \\
\hline $35-93$ & $\begin{array}{l}08823: 93 \\
7: 45\end{array}$ & $\begin{array}{l}\text { Cedar } \\
\text { Grove }\end{array}$ & 417 & (3) & & 39.5 & 9.00 & 9.86 & 81.14 & 417 & 9.50 & 70.26 & 3443 \\
\hline
\end{tabular}

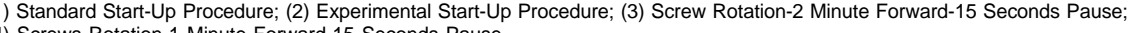


A single test sized condenser was designed to mount on one of the 10 inch diameter inspection ports of the screw reactor. The vapors from the screw reactor first enter a small tank only two feet from the inspection port where tars and solid particles separate. Originally a short packed column was installed on the outlet of this tar separator tank to further condense tars and prevent entrainment. A water cooled condenser was installed above the packed column to condense coal liquids with the non-condensibles going to the flare line. This condenser was used along with the existing condensers to test the design. Plugging of the packed column and tar coating the condenser tubes caused rejection of the design. It was concluded that a condenser system had to be open with no internal parts to permit tar accumulation. The tar separator tank is part of the condenser system that is now installed on the screw reactor. A 14 inch diameter spray type condenser was designed and built to replace the three original condensers. The condenser has a 14 inch diameter, five feet long vertical open section that permits separation of most tar which drains back to the tar separator tank. The vapors then enter the condenser section where two Bete spray nozzles provide a dense spray of coal liquids. Good contact is obtained between the vapors and liquid spray. A pump circulates coal liquids from the bottom of the condenser section through a water cooled heat exchanger and through the spray nozzles. The temperature of the circulating coal liquids is controlled in the range of $220^{\circ} \mathrm{F}$ to $230^{\circ} \mathrm{F}$ which prevents condensation of water from the non-condensibles. Coal liquids that condense overflow to a weigh tank. The non-condensibles and water are flared. In a commercial plant, the non-condensibles will provide fuel for the process. The tar separator prevents solids and most heavy tars from entering the condenser section. The tars that enter the condenser are dissolved by the hot circulating coal liquids. The new condenser replaced the three original condensers and they were removed.

Two other improvements were made to the screw reactor system which were necessary for higher coal feedrates and longer test runs. The original star valve coal feeder was undersized and limited the coal feed rate. It was removed and the coal conveyor screw was converted to a variable speed coal metering screw. The vapor seal required in the coal feed stream was provided by removing a short section of the screw's flights near the coal entry port on the screw reactor. The gap created causes a plug to form in the screw and blocks the flow of gases into the coal weigh bin. The second improvement involved sealing of the screws' shafts. The original stuffing boxes on each end of the screws did not seal well due to wobbling of the shafts caused by less than perfectly straight screws. The stuffing boxes were bolted rigidly to the screw reactor ends and as the screw shafts wobbled, the stuffing boxes' attaching bolts were sheared. The boxes were remounted using springs to hold them against the screw reactor ends with high temperature gaskets between the boxes and ends. This permits the stuffing boxes to move as the shafts wobble and minimizes leaks. This is a less than perfect solution but permits operation of the screw reactor, Christian Engineering of San Francisco, California, the builder of the screw reactor and the expected builder of the commercial unit, has a patented flexible seal that will seal a wobbling shaft. These seals will be specified for the commercial unit. 
David W. Camp of the Lawrence Livermore National Laboratory recommended that the screw reactor screws speed be increased. His work indicated that heat transfer in a heated screw increased with the square root of the screw rotation speed. The speed of the screws was increased by 40 percent by installing a larger drive sprocket on the hydraulic motor. Runs before and after this change did not result in an increased heat transfer rate as shown by the following summary.

The two test runs were essentially identical except for the screws speed, If the higher speed had increased the heat transfer rate in test run 7-94, the char percent volatiles from this test run would have been lower than for the char from test run 6-94. 


\section{SUMMARY OF CMGU TESTS}

\begin{tabular}{|c|c|c|c|c|c|c|c|c|c|c|c|c|c|}
\hline $\begin{array}{l}\text { Run } \\
\text { No. }\end{array}$ & $\begin{array}{l}\text { Date \& } \\
\text { Hrs./Min. } \\
\text { Duration }\end{array}$ & Coal Used & $\begin{array}{l}\text { Coal } \\
\text { Feed } \\
\text { Rate } \\
\text { Lb/Hr }\end{array}$ & $\begin{array}{l}\text { Forward } \\
\text { Reverse } \\
\text { Ratio }\end{array}$ & $\begin{array}{l}\text { End } \\
\text { Coal } \\
\text { Temp } \\
{ }^{\circ} \mathrm{F}\end{array}$ & $\begin{array}{l}\text { Liquid } \\
\mathrm{Lb} / \mathrm{Hr}\end{array}$ & $\begin{array}{l}\text { Char \% } \\
\text { Volatile } \\
\text { Avg. }\end{array}$ & $\begin{array}{l}\text { Char \% } \\
\text { Ash } \\
\text { Avg. }\end{array}$ & $\begin{array}{l}\text { Char \% } \\
\text { Fixed } \\
\text { Carbon } \\
\text { Avg. }\end{array}$ & $\begin{array}{l}\text { Char } \\
\mathrm{Lb} / \mathrm{Hr}\end{array}$ & $\begin{array}{l}\text { Coal } \\
\text { Liq. } \\
\%\end{array}$ & $\begin{array}{l}\text { Char } \\
\%\end{array}$ & $\begin{array}{l}\text { Btu/Lb } \\
\text { of } \\
\text { Coal }\end{array}$ \\
\hline 6-94 & $\begin{array}{l}2 / 21 / 94 \\
6: 00\end{array}$ & laeger B & 852 & (1) & 1266 & 67 & 7.40 & 7.75 & 83.52 & 647 & 7.8 & 75.93 & 1957 \\
\hline 7-94 & $\begin{array}{l}3 / 1 / 94 \\
5: 52\end{array}$ & laeger B & 857 & (2) & 1263 & 70 & 9.99 & 7.40 & 82.61 & 653 & 8.1 & 76.22 & 1863 \\
\hline
\end{tabular}

\section{(1) Screw Rotation - 2 Minutes Forward-15 Seconds Pause (15-17 RPM) \\ (2) Screw Rotation - 1 Minutes Forward-30 Seconds Pause (25-27 RPM)}

The higher screws' speed also did not require more power to drive the screws and the larger sprocket remains on the screw reactor. 
Environmental Protection Work

Since the non-condensable gases from the condenser system are the only waste stream of the CTC mild gasification process, most of the environmental protection efforts have been concentrated on this stream.

The original condenser system used indirect water cooling to remove process heat and water pollution was not a problem. This is also true for the new condenser system. Also, in both cases, the non-condensibles were and are flared. In a commercial plant, the non-condensibles will be used as process fuel and producing a clean non-condensable gas stream will be important. Efforts were concentrated on removing condensable components from the screw reactor off-gases. The replacement spray contact-type condenser is a more efficient vapor-liquid contact unit but a small amount of coal liquids remains in the flared gases. A six-inch diameter, 10 feet long demister was installed after the condenser in the flare line. The demister was packed with stainless steel machine turnings. Approximately five pounds per hour of water with a very small amount of coal liquids was collected by the demister from the flare stream. Cooling the outside of the demister with water spray did not significantly increase the performance of the demister. When sampling the flare stream above the demister, a black, oily material condenses in the sample tube. Flare gas was bubbled into water in a glass container two to four inches below the surface. An oil film formed on the water surface. Using the water bubbler as an oil trap ahead of the sample tube eliminated the black, oily material in the sample tube. It is believed that an aerosol suspension of coal liquids in the flare stream, with water vapor as the carrier, allows a very small amount of coal liquids to reach the flare, Bubbling the flare gas in water breaks this aerosol suspension. The transport mechanism of a gas bubbling in a liquid subjects the gas to a slight positive pressure causing the extremely small aerosol droplets to collapse, Based on the small bubbler experiments, a bubble-type scrubber was fabricated to handle about half of the flare stream. The stream from the scrubber burned cleanly. The remaining stream burned as usual with some black smoke generated. Air at a rate of $10 \mathrm{CFM}$ blown into the flare line about five feet below the flare flame reduces the level of smoke from the flame.

When coal is pyrolyzed, phenolic compounds area significant component of the volatiles. Any water separated as liquid from these volatiles contains phenols. In the CTC PDU the water vapor is flared with the non-condensibles. In a commercial plant, the water vapor will be fed to a combustion unit with thenon-condensibles. This results in a very small amount of contaminated water requiring treatment.

The following tables list the compositions of the non-condensibles after the demister and after the bubble scrubber, respectively, 
Non-Condensibie Gas Analysis At Top Of Demister

Run \#30-93

Lab. No. CTC \#77

$\mathrm{H}_{2}$
$\mathrm{O}_{2}$
$\mathrm{~N}_{2}$
$\mathrm{CH}_{4}$
$\mathrm{CO}$
$\mathrm{CO}$,

$\mathrm{H}_{2} \mathrm{~S}$

COS

$\mathrm{SO}_{2}$

$\mathrm{CH}_{4}$

$\mathrm{C}_{2} \mathrm{H}_{6}$

$\mathrm{C}_{2} \mathrm{H}_{4}$

$\mathrm{C}_{3} \mathrm{H}_{8}$

$\mathrm{C}_{3} \mathrm{H}_{6}$

$\mathrm{IC}_{4}$

$\mathrm{Nc}_{4}$

$\mathrm{C}_{4} \mathrm{H}_{8}$

Isobutylene

2-methylbutane

2,2-dimethyipropane

$\mathrm{Nc}_{5}$

$\mathrm{C}_{5} \mathrm{H}_{10}$

2-methylpentane

3-methylpentane

2,2-dimethylbutane

$\mathrm{Nc}_{6}$

$\mathrm{C}_{6} \mathrm{H}_{12}$

$\mathrm{Nc}_{7}$

$\mathrm{C}_{6} \mathrm{H}_{6}$

Toluene

p\&m-xylenes

o-xylenes
$21.83 \%$

$1.92 \%$

$7.82 \%$

$44.34 \%$

$2.99 \%$

$2.57 \%$

$8729.6 \mathrm{ppm}$

$144.5 \mathrm{ppm}$

$8.5 \mathrm{ppm}$

$7.88 \%$

$3.11 \%$

$19046.6 \mathrm{ppm}$

$26989.7 \mathrm{ppm}$

$981.5 \mathrm{ppm}$

$3785.6 \mathrm{ppm}$

$4407.5 \mathrm{ppm}$

$3411.1 \mathrm{ppm}$

$1156.5 \mathrm{ppm}$

$547,9 \mathrm{ppm}$

1270,3 ppm

$1261.6 \mathrm{ppm}$

194,3 ppm

184,3 ppm

$72.1 \mathrm{ppm}$

$466.0 \mathrm{ppm}$

$615.4 \mathrm{ppm}$

$219.0 \mathrm{ppm}$

$879.0 \mathrm{ppm}$

$615.7 \mathrm{ppm}$

240,9 ppm

$83.8 \mathrm{ppm}$ 
Non-Condensible Gas Analysis After Bubble Scrubber

$\begin{array}{lr}\mathrm{CH}_{4} & 54.0 \% \\ \mathrm{H}_{2} & 37.9 \% \\ \mathrm{CO} & 5.0 \% \\ \mathrm{~N}_{2} & 6.4 \% \\ \mathrm{O}_{2} & 1.1 \%\end{array}$

The table below shows the organic compounds contained in water decanted from coal liquids.

\section{Organic Compounds in Water Decanted From Coal Liquids \\ GC and GC/MS Results}

Compound Contained

Phenol

Ortho-cresol

Mets-cresol

2.3,6-Trimethylheptane

3,6-Dimethyldecane

5-Propyldecane

2.3,5-Trimethyldecane
Approximate Concentration, \%

0.07

0,05

0.04

0.03

0.06

0.10

0.10

During the screw reactor operations, a total of 52 different coals have been successfully pyrolyzed, The coal types range from non-caking, low volatile, mid-volatile, and high volatile coals. In addition waste rubber from tires, municipal solid waste (MSW), and industrial solid waste have been processed on a limited basis. The screw reactor is designed to process coking coals to produce char for converting to coke. The major accomplishment of the project is that the basic design of the screw reactor has been proven for scale-up to a commercial unit.

\section{TASK 5: CONTINUOUS BRIQUETTING AND COKING}

1993:

In late 1993 it became apparent that to progress toward a commercial plant the coking phase of this project should be expanded and revised. One hundred seventy-two benchscale tests had been conducted which were far beyond the original scope of this project. Something new was learned from each test but that would continue indefinitely. Testing 
new binders and different new coals could be an ongoing and never ending study. This project is the first in the world to produce blast furnace quality formed coke. The coke tested by UEC with a CRI of 30.4 and CSR of 67.0 is significant. This proved that the coke quality is not just an unsupported claim but is a fact supported by an independent third party.

To continue to move toward market acceptance, quantities of coke were needed which would allow for large scale testing of CTC coke. A test in a blast furnace would require 100,000 tons of coke or more. The cost of that test would be prohibitive and presented an impossible production level for CTC. A test in a cupola using foundry coke could be made with as little as eight tons.

Preliminary work began on an extension of the coking phase of this project. This extension would construct a facility to continuously produce coke in quantities which would facilitate cupola testing. The unique feature of this facility is it was be built with used equipment. Coal Technology engineers researched the used equipment market for the best possible equipment for this project. The primary focus of this search was the calciner or furnace. With the help of various used equipment brokers, the entire United States, Canada, and the United Kingdom were searched. Since no calciner was built for this application, many characteristics were considered such as:

Operating temperature and heat profile capabilities

Capacity

Cost of modifications

Cost of relocation

Coke product degradation

In addition to the calciner, a used briquette was located and price negotiated which made large briquettes to be used for foundry coke or could be broken to form the irregular shapes of the proper size for blast furnace coke.

Excess government owned equipment was also explored for use on this project. Three pieces were found: a motor control center, a weigh feeder, and a roll crusher which were valuable to this project and were transferred to it.

1994:

After carefully monitoring the used equipment market as well as the PETC/DOE excess inventory, work began on the continuous coke extension. The following key components were identified and ordered in early 1994. These were: 


$\begin{array}{ll}\text { Component } & \text { Vendor } \\ \text { Kiln } & \text { Universal Process Equipment } \\ \text { Calciner } & \text { Universal Process Equipment } \\ \text { Hot Oil Heater } & \text { Universal Process Equipment } \\ \text { Heated Mixer } & \text { Scott Equipment } \\ \text { Motor Control Center } & \text { PETC/DOE } \\ \text { Roll Crusher } & \text { PETC/DOE } \\ \text { Weigh Belt } & \text { PETC/DOE }\end{array}$

Installation of the continuous coke pilot plant equipment began in the Second Quarter of 1994. Almost all components of the pilot plant were used pieces of equipment. Modifications and repairs were required to provide a continuous system to produce 500 to 700 pounds per hour of formed coke. Ten of the 14 major pieces of equipment were set by April including the three largest components: the briquette, curing calciner, and high temperature kiln. Remaining equipment on order at that time included two screw conveyors, the briquette conveyor, and the coke cooler. Start-up of the pilot plant was scheduled for late 1994.

Construction and engineering continued in parallel on the continuous coke process demonstration plant. The following pieces of equipment were installed in the last quarter of 1994:
Hot Oil Heater
Asphalt Metering Pump
Binder Coal Feed Screw
Char Feed Screw
Green Briquette Conveyor
Rotary Air Lock
Diverter Valve
Flue Gas Stacks

Each piece of equipment required a support structure and utilities. In addition to normal construction tasks, much of the used equipment had to be repaired. The used pieces that were repaired were the calciner, hot oil heater, kiln furnace, and motor control center. Other pieces had to be modified to run at the PDU designed production rate of 500 to 700 pounds per hour. Equipment modified to run at the required production rate were the briquette, calciner, and kiln. The K-tron weigh feeder and volumetric feeders were calibrated.

Only minor problems occurred during initial start-up. A cold run was made in the calcining portion of the process. Green briquettes were fed into the green briquette conveyor through the air lock, diverter valve, calciner and kiln. One area had a hanging 
problem which was corrected. Angles and rotation speeds were set so that the calciner and kiln each had about a 30 -minute retention time.

In parallel with construction of the PDU, bench-scale work continued on these large foundry sized briquettes. Past experience with the blast furnace sized briquettes was helpful in quickly obtaining quality briquettes with the large briquettes. However with the large briquettes, the technology had to be modified to optimize the product for use in the foundry or blast furnace. Some of the techniques used on the small briquettes did not work on the large briquettes. It was anticipated that ultimately coke quality would improve somewhat with this PDU over the batch coke produced. This was due to process enhancements and more precise control of variables available with the continuous process.

At this point in 1994 the start-up procedure was being developed. A concern was heat cycles on the kiln. Heat cycles are damaging to a kiln. The plan was to run the kiln for a week at a time around the clock at a minimum. During short testing, changing parameters one at a time on small batches had to be avoided. Bringing the kiln up to operation temperature would take 8 to 12 hours. Each process change would have to be allowed to reach equilibrium and then sampled and tested again while the system was running. That took about two hours per modification or 1000 pounds of product coke. It was surmised that after a week of continuous running, the PDU could be halted, the results analyzed, the next test plan formulated and the system started for another week of continuous running.

It was planned that all coke produced in the start-up phase that was not of acceptable quality would be recycled to replace char. Because of the flexibility of the process, there should be very little waste. It was impossible to predict the quantity of unacceptable coke that would be produced in the start-up, but it was expected to be measured in tons rather than pounds, A week's production would produce approximately 36 tons of coke.

Construction of the continuous coke PDU was completed in October 1994. One start-up problem encountered involved the drive for the twin tube calciner. The first drive installed proved too small to rotate the tubes with the friction of the four large packing glands required to seal the tubes. Increasing the drive power and reworking the packing glands solved this problem,

The initial tar binder metering system using a variable speed gear pump did not provide accurate control of the tar addition rate due to plugs in the tar line to the mixer. This metering system would have worked with asphalt but a vendor for small quantities of asphalt could not be found. The pitch was first added to the char/binder coal feed but that accumulated in the feed screw and caused the feed screw to stall. The addition of pitch to the raw material mix was solved by feeding with a volumetric feeder to the mix at the heated mixer. 
At the same time as the PDU was being constructed, work was being done on a benchscale to find an acceptable formula for the large briquettes.

The following table shows five large briquette formulations. The first and last formulations were eliminated due to low strength as measured by the Modified Drop Shatter Test. The other three formulations provided guidelines for production of formed coke for evaluations at commercial coke producers and coke users.

\begin{tabular}{||l|r|r|r|l||}
\hline \begin{tabular}{|} 
Briquette \\
Formula
\end{tabular} & $\begin{array}{l}\text { Drop } \\
\text { Shatter } \\
\text { Test }^{*}\end{array}$ & CSR & CRI & Comments \\
\hline $\begin{array}{l}\text { 15\% Pitch } \\
85 \% \text { Char }\end{array}$ & $38,9 \%$ & 47.9 & 32.2 & $\begin{array}{l}\text { High volatiles, intended to show the } \\
\text { role of pitch and volatiles in coke. }\end{array}$ \\
\hline $\begin{array}{l}\text { 80\% Coke } \\
10 \% \text { Pitch } \\
10 \% \text { Coal }\end{array}$ & $96,2 \%$ & 3.3 & 40.9 & Similar to existing formed coke plant. \\
\hline $\begin{array}{l}\text { 40\% Coke } \\
\text { 40\% Char } \\
10 \% \text { Pitch } \\
10 \% \text { Coal }\end{array}$ & $82.1 \%$ & 0.0 & 55.0 & $\begin{array}{l}\text { Possible raw material mix for } \\
\text { commercial plant. }\end{array}$ \\
\hline $\begin{array}{l}77 \% \text { Coke } \\
15 \% \text { Coal } \\
8 \% \text { Pitch }\end{array}$ & $95.7 \%$ & 0.0 & 49.8 & $\begin{array}{l}\text { Minimize pitch and volatiles and } \\
\text { maximize coal. }\end{array}$ \\
\hline $\begin{array}{l}79 \% \text { Char } \\
13 \% \text { Coal } \\
8 \% \text { Pitch }\end{array}$ & $26.0 \%$ & 38.1 & 32.2 & Show how char substitutes for coke. \\
\hline \hline
\end{tabular}

*Modified Drop Shatter Test. Three briquettes (about nine pounds) are weighed and then dropped four times from six feet onto a concrete floor. The material is then screened on a three-inch screen with the amount retained reported.

1995:

Pilot plant start-up debugging continued. The problem of plugging at various places was addressed. The briquettes along with the fines and the broken briquette would bridge in the chutes and stop the flow of material. The original design of the transition chutes was for pillow shaped briquettes which after tumbling through the calciner and kiln become egg-shaped. The briquettes readily roll and it was a concern that they would tend to roll rapidly through the calciner and kiln and obtaining an acceptable residence time would 
be difficult. With that in mind, the chutes were designed steeper than the briquettes needed to roll and steeper than the angle at which the briquettes would slide but with as little additional slope as possible to reduce breakage and to keep the briquettes from rolling half-way through the kiln and calciner. In actual practice with fines from the parting line (flash) and from abrasion and an occasional broken briquettes, the material would not flow well and the chutes would plug.

The chutes were redesigned steeper and wider to eliminate the plugging problem. These redesigned chutes were tested in an extended run and worked well. The kiln discharge port tended to plug. This chute was already vertical but was too small in diameter (eight inches). The chute was increased to 12 inches diameter which eliminated this final plugging problem.

In order to reduce risk and to develop support data on how continuous coke works in a cupola, testing was set up with the help and support of a major coke manufacturer and a major coke consumer. The first test required a one-ton sample which was made in January. This coke sample was tested in February in a small, 24 inch diameter cupola. Production cupolas are typically 100 inch diameter or larger. Although small, this was an actual cupola test and success in this actual application greatly supported CTC's efforts to have this technology accepted in the marketplace.

The test was a great success. The test was done using first 25 percent formed coke, then 50 percent formed coke and finally 100 percent formed coke. The coke performed well; the melt went normally. Carbon pick-up was at acceptable levels, temperatures were within the desired range, and in general the coke replaced conventional coke with very little change. This test was a major step toward proving the acceptability of the CTC formed coke as it was an actual test in a cupola and not a lab test.

Before the ton of coke was made, the recipe used with these large 6 inches $\times 5$ inches $x 4$ inches briquettes was further refined. Large briquettes made using the same recipe as for good quality small briquettes will not do well on a drop shatter test. It was collectively determined that the drop shatter test is important in foundry coke and that specification should be met first. To meet this requires a little reduction in binder coal and the addition of about 15 percent coke breeze. This modification slightly reduces the CSR and CRI characteristics but increases the results of the drop shatter test, It was decided that for this test the briquettes would have a 90 percent retention on a 3 inch screen after four drops from six feet. The following chart lists the mix recipe with the coke characteristics. 


\begin{tabular}{||l|c|c|c||}
\hline \hline Briquette Formula & Drop Shatter Test & CSR & CRI \\
\hline $10 \%$ Pitch & $65,9 \%$ & 1.3 & 32.0 \\
$10 \%$ Coal & & & \\
$64 \%$ Char & & \\
\hline $16 \%$ Coke & $95.3 \%$ & 9.6 & 42.1 \\
\hline $\begin{array}{l}12 \% \text { Pitch } \\
10 \% \text { Coal } \\
15 \% \text { Coke } \\
63 \% \text { Char }\end{array}$ & & & \\
\hline \hline
\end{tabular}

This material recipe is not the final ultimate recipe but is close for foundry briquettes. When large shapes are required, some of the same rules used for conventional coke are applicable for continuous coke. One of these rules is the addition of coke breeze to the recipe (10-15 percent). Another raw material that needs to be studied for foundry coke is anthracite, These recipe changes will be studied as the opportunity presents itself.

A two-ton sample of coke briquettes was made for a test in a 62-inch production cupola. This test was intended to reduce risk and increase credibility of the CTC/DOE continuous coke process.

After the first test in the 24-inch cupola and before the coke was made for the second test in the 62-inch production cupola, several problem areas were identified and corrected in the PDU. These solutions were not intended to be final but were made just to make the sample for the second test. Two general problem areas were identified. First, the raw material metering systems were inconsistent and ineffective. The pitch would run a short while and then solidify at some point causing the pitch feed to stop completely. The char feeder would feed well for a while and then stall causing that feed to completely stop. Each of these stoppages would cause large quantities of bad coke to be produced. To eliminate these problems for the second test, it was decided to mix the raw materials manually. To mix manually, a larger batch mixer and a better raw material heating system were required. To locate the batch mixer, six used equipment dealers were contacted and each responded with specifications on mixers which he thought would meet the requirements. Four of these used equipment dealers were then visited and the mixers visually inspected, After each piece was evaluated, the CTC engineering team then weighed the advantages and disadvantages of each mixer, A mixer was then chosen and ordered.

To increase the heating capacity, a transfer conveyor was jacketed at a local machine shop for hot oil. With a larger requirement for hot oil, a larger hot oil pump was required, This large hot oil pump was located and installed. 
In parallel with the process demonstration unit work, equipment vendors continued to be identified and evaluated, Another potential calciner vendor for the commercial plant project at Princeton, West Virginia, was located and visited. This company is Swindell Dressier International. It has over 100 years in business and has vast experience in calcining. This experience includes closely related experience with furnaces made for carbon cathode electrodes production made from petroleum coke and coal tar pitch.

Work began on using non-caking Western coal to make blast furnace coke. Preliminary test recipes were made with varying success (chart follows). Work was done in two directions, first to replace a portion of the highly reactive Western coal with another carbon form such as petroleum coke, conventional coke breeze or char from Eastern coking coal. This theory worked to some degree dependent on the coke quality required and on what proportion of the Western coal is acceptable to be replaced. Nippon Steel has had success with this approach using up to about 50 percent non-caking coal,

The second theory tried was to actually change the highly reactive isotropic carbon forms found in non-caking coal to the less reactive anisotropic carbon forms found in caking coal. This was explored in two areas. First, coke was made at higher than usual final temperatures. In the production of petroleum coke, the temperature of the coke has a relationship with the molecular structure and with the reactivity of the coke. Secondly, it has been suggested by a leading petrographic expert that petroleum pitch will change isotropic to anisotropic carbon forms in non-caking Western coal, Several petroleum pitch candidates were examined in coke made from non-caking coal to see if the reactivity is reduced. These theories were exciting because if blast furnace coke could be made from non-coking coal, it would greatly increase the raw material sources for coke. 


\section{Comparison of CRI and CSR With Geneva Steel's Coke and the Cokes Made From Western Coals By the CTC/CLC $\circledast$ Process}

\begin{tabular}{||l|c|c||}
\hline \multicolumn{1}{|c|}{ Coke I.D. } & CRI & CSR \\
\hline Geneva Steel's Coke & 35.8 & 52.3 \\
\hline Geneva Steel's Purchased Coke (China Coke) & 22.6 & 64.0 \\
\hline $\begin{array}{l}\text { CTC Coke Made From Geneva Blend Coal (A) } \\
\text { 70\% Char, 20\% Binder Coal, 10\% Pitch }\end{array}$ & 52.0 & 37.7 \\
\hline $\begin{array}{l}\text { CTC Coke Made From Geneva Blend Coal (B), laeger Binder } \\
\text { Coal, 68\% Char, 17\% Binder Coal, 15\% Pitch }\end{array}$ & 34.0 & 49.3 \\
\hline $\begin{array}{l}\text { CTC Coke Made From Sufco Coai and laeger Binder Coal } \\
\text { 65\% Char, 17\% Binder Coal, 18\% Pitch }\end{array}$ & 53.0 & 20.4 \\
\hline $\begin{array}{l}\text { CTC Coke Made From Geneva Coai and Lady H Binder Coal } \\
\text { 58\% Char, 34\% Binder Coal, 8\% Pitch }\end{array}$ & 72.8 & 0.0 \\
\hline $\begin{array}{l}\text { CTC Coke Made From Sufco Coai and Sufco Binder Coai } \\
\text { 65\% Char, 17\% Binder Coal, 18\% Pitch }\end{array}$ & 72.3 & 0.0 \\
\hline $\begin{array}{l}\text { CTC Coke Made From Skyline Coal and ViCC's Binder Coal } \\
\text { 65\% Char, 17\% Binder Coal, 18\% Pitch }\end{array}$ & 77.9 & 0.0 \\
\hline $\begin{array}{l}\text { CTC Coke Made From Geneva Blend Coai } \\
\text { 65\% Char, 24\% laeger Binder Coal, 11\% Pitch }\end{array}$ & 39.8 & 40.7 \\
\hline $\begin{array}{l}\text { CTC Coke Made From Sufco Coai } \\
\text { 65\% Char, 24\% Lady H Binder Coal, 11\% Pitch }\end{array}$ & 72.1 & 3.8 \\
\hline $\begin{array}{l}\text { CTC Char Made From Sufco Coal } \\
\text { 65\% Char, 24\% Lady H Binder Coal, 11\% Pet. Pitch (Gilsonite) }\end{array}$ & 72,6 & 1.6 \\
\hline $\begin{array}{l}\text { CTC Coke Made From Geneva Blend Coal } \\
\text { 65\% Char, 24\% laeger Binder Coal, 11\% Pet. Pitch }\end{array}$ & 35.4 & 27.4 \\
\hline \hline
\end{tabular}

Nine preliminary test runs were made using a weakly caking Colorado coal to produce metallurgical grade coke. These tests showed that this coal has to be blended with a stronger caking, higher rank coal if it is to be used as a raw material for coke production. The following tables show the results of blending 60 percent Colorado coal with 40 percent stronger caking coals and the coke characteristics from these blends. 


\begin{tabular}{||l|r|r|r|r|r||}
\hline \hline Specification & Sewell & Blend & \multicolumn{1}{l|}{ Pocahontas } & \multicolumn{1}{l|}{ Blend } & \multicolumn{1}{l|}{ Target } \\
\hline Rank & 4.31 & 3.59 & 7.09 & 4.70 & 4.5 \\
\hline Max. Mean Reflectance & 1.35 & 1.07 & 1.61 & 1.18 & 1.4 \\
\hline FSI & 8.00 & 7.00 & 9.00 & 7.50 & 8.0 \\
\hline Ash & 4.22 & 6.82 & 5.33 & 7.26 & $<8.0$ \\
\hline Stability & 59.00 & 44.80 & 58.00 & 44.40 & $>\mathbf{5 8 . 0}$ \\
\hline
\end{tabular}

Using the above blending approach to make char in a 60 percent Colorado/40 percent Sewell or Pocahontas blend, the following coke was subsequently made.

\begin{tabular}{||l|l|l||}
\hline \hline Char & CRI & CSR \\
\hline Colorado/Sewell & 40,2 & 49.5 \\
\hline Colorado/Pocahontas & 32,3 & 65.0 \\
\hline \hline
\end{tabular}

The results of this work with weakly caking coal indicated that quality blast furnace coke could be made using it as a major raw material source.

Eight tons of 6 inches $\times 5$ inches $\times 4$ inches CTC/DOE formed coke were produced for a 100 percent use test at a commercial foundry. The test sample was used as a direct replacement for 50 percent of the coke charge. Results were excellent, tap temperatures increased, carbon pickup improved, sulphur levels decreased and the melt rate stayed at high levels during the test. No' negative characteristics were detected, The technical manager of the production cupola stated, "In the final analysis, the blend of 50\% CTC coke had a positive impact on our operation." At the time this was the longest test run of CTC continuous coke. Each test further supported the acceptability of CTC continuous coke in the cupola and helped reduce any perceived risk.

During the course of this production, process improvement work continued and alternative coking methods were evaluated. A shuttle kiln was used to coke a small portion of the green briquettes. Coke from the shuttle kiln showed a 10 point increase in CRI. Other types of coking methods considered were a tunnel kiln and a rotary hearth furnace. The foundry test was successful.

Discussions with a large European steel and coke manufacturer and a US. steel manufacturer were held with the objective of using the CTC/DOE continuous coke technology in a commercial plant, The basic technology was slightly modified for this application and many technical questions were discussed and answered. A basic flow sheet was also made for this application. Some of the areas of discussions were what 
are the technical limits of a scale-up and is a 20 times scale-up possible; what would be the reasonable life of the reactor; and how reliable would it be in a continuous commercial application. Reactor heat transfer calculations for pyrolysis were reviewed, Reactor process variables such as retention time, screw speed, temperature, and forward/reverse motion were evaluated. The capital and economic calculations were reviewed. The funding and ownership were analyzed. A mass balance was studied. A heat balance was developed. Heat efficiency was evaluated including regeneration of heat and energy recovery. Process data were analyzed to clarify how variables within the process affect quality, economics, throughput and emissions, The type and size of the coking furnace and basic plant layout were discussed. Economic considerations were discussed including investment costs and the scope of these investment, hidden costs in infrastructure and utilities, operating costs and a general business plan, Lastly, the market for continuous coke was evaluated. This commercial plant is designed to produce 60,000 TPY. Equipment diagrams of the char and coke production operations are included in the Appendix, Figures 12 and 13.

Commercial sized coking furnaces were studied. At present the tunnel kiln appears to have the most advantages. One of the major advantages is cost. A tunnel kiln on a commercial scale was quoted at $\$ 2,000,000$. A rotary hearth furnace on the same scale was quoted at $\$ 7,000,000$. Another advantage is the briquettes are not handled or tumbled while they are taken through their heat cycle. At some point in the heat cycle while the bitumen is soft and while the binder coal is going through the plastic zone, the briquettes are fragile. Not handling them while they are fragile will greatly increase yield by reducing breakage and abrasion. A higher yield will impact on the economics which is always of prime importance in a commercial project.

Two 20-ton tests were discussed with General Motors, One test would be in a production cupola and the other in the research lab cupola. These tests were to be done on a costshared basis. Success in these tests would eliminate any lingering doubts about the performance of the CTC continuous coke in the cupola. Investor confidence would increase and risk will be reduced after successful completion of these two tests done jointly with General Motors. This program would be an excellent way to benefit the development of a new manufactured coke product designed to give optimum furnace performance, To do this testing, CTC's contract was amended.

In summary, this tentative cooperative test program was structured as follows:

1. CTC would pay for the coal and other binding ingredients, make the coke, ship the coke to GM, and travel to be present during the testing program at CTC's expense.

2. CTC would make modifications to our existing pilot plant at a cost of about $\$ 40,000$ to allow for continuous production of the coke. 
3. CTC's total cost including labor, shipping, lab testing, equipment modification, etc. would be about $\$ 200,000$.

4. GM would test the coke in both research and production cupolas at GM's cost. The production test would be using a blend of CTC/DOE continuous coke and conventional oven coke. The second test would be conducted at the Pellestar, Ltd. cupola and would most likely occur in two heats, both to be funded by GM. The first would be a baseline heat using 100 percent conventional slot oven coke as the fuel/carburizer requirement for the cupola. The second heat would utilize 100 percent CTC/DOE continuous coke as the fuel/carburizer requirement. Data from the two heats would then be compared as the basis of a report. The Pellestar test will occur after successful completion of the production test. The production test would occur at either GM's Defiance, Ohio, foundry or at the Saginaw Metal Casting Operations Plant in Saginaw, Michigan.

5. A combined publication would be made from the data obtained in the tests.

6. Time schedule for the first shipment of coke to GM was tentatively set for midFebruary 1996, for the coke production testing soon after and a second shipment of coke in early August, 1996, for the research test.

Work began on producing the first test sample and a mid-February ship date was the target.

Five screw reactor runs were made using non-caking coal from the Rosebud seam. The first was to make char for the production of coke. The raw coal analysis was as follows:

\section{As Received $\quad$ Dry}

$\begin{array}{lrr}\text { Moisture, \% } & 27.39 & - \\ \text { Volatiles, \% } & 31,25 & 43.05 \\ \text { Ash, \% } & 5.52 & 7.60 \\ \text { Fixed Carbon, \% } & 35.84 & 49.35\end{array}$

After the reactor run, the char analysis was as follows:

\section{As Received}

$\begin{array}{lc}\text { Moisture, \% } & 0.51 \\ \text { Volatiles, \% } & 11.40 \\ \text { Ash, \% } & 12.26 \\ \text { Fixed Carbon, \% } & 75.83\end{array}$


Coke was made with this char using CTC/DOE technology with the following results.

$\begin{array}{lr}\text { CRI } & 56.4 \\ \text { CSR } & 19.2\end{array}$

Coke made from this non-caking coal will not meet the quality specifications of coke made from coking coal. However, these results have both major coal producers and coke users very excited because of the very low cost of the coal and subsequent coke. It is possible that this low cost coke could be blended with conventional coke and greatly reduce the total cost of coke in the blast furnace and cupola.

The next four screw reactor runs were made to test the reactor as a dryer for reducing only the moisture content while maintaining the stability of the coal and preventing spontaneous combustion. Conditions were modified in each run from data obtained in the prior run to bring the moisture down while maintaining the stability, The analysis of the dried coal can be compared to the coal as received in the following table.

\section{Dried Coal As-Received Coal}

$\begin{array}{lrr}\text { Moisture, \% } & 0.61 & 27.39 \\ \text { Volatiles, \% } & 34.57 & 31.25 \\ \text { Ash, \% } & 7.00 & 5.52 \\ \text { Fixed Carbon, \% } & 57.82 & 35.84\end{array}$

Size analysis of dried coal:

\begin{tabular}{|c|c|c|}
\hline Size & wt., \% & Cum. Wt., \% \\
\hline$+3 / 8^{\prime \prime}$ & 29.8 & 29.8 \\
\hline 3/8" x 4 mesh & 23.1 & 52.9 \\
\hline 4 mesh $\times 6$ mesh & 24.0 & 76.9 \\
\hline 6 mesh $\times 16$ mesh & 19.0 & 95.9 \\
\hline 16 mesh $\times 30$ mesh & 2.5 & 98.4 \\
\hline-30 mesh & 1.6 & 100.0 \\
\hline
\end{tabular}

The coal was completely dried with no loss of volatiles and stability was maintained.

In addition to the coking work using non-coking coal from the Rosebud seam, coking work on SynCoal made from Rosebud coal was completed. Rosebud SynCoal is made in conjunction with the U.S. Department of Energy under the Clean Coal Technology Program. This technology enhances Powder River Basin coal by reducing moisture and sulfur and substantially increases Btu content. The goal was to produce acceptable foundry coke with a majority of SynCoal as feedstock. 
The analysis follows:

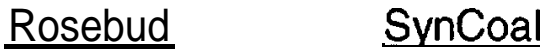

$\begin{array}{lrr}\text { Moisture, \% } & 27.39 & 1.57 \\ \text { Volatiles, \% } & 31.25 & 36.61 \\ \text { Ash, \% } & 5.52 & 8.36 \\ \text { Fixed Carbon, \% } & 35.84 & 53.46\end{array}$

An initial test was done using 25 percent SynCoal, 25 percent char from SynCoal, 12 percent coke breeze and 38 percent binders. These 6 inches $\times 5$ inches $\times 4$ inches briquettes had a 69.4 percent shatter retention on a three-inch screen. We planned a test matrix which was developed on CTC's experience, knowledge and judgment.

In parallel with the General Motors' test, work was done on making char for Elkem Metals from a Pittston coal. It was tentatively planned to make a 20 -ton char sample for testing. Initially a two-ton sample was made for evaluation. This initial test sample went well and is currently being studied to determine how best to proceed.

Coal Technology Corporation conducted a test program with Western SynCoal Company to upgrade a sub-bituminous dried coal product from the Western Energy Company's Rosebud Mine at Colstrip, Montana. Western SynCoal supplied approximately one ton of their dried coal product to accomplish this test program.

The as-received samples were analyzed for proximate (moisture, ash, volatiles, fixed carbon) by CTC through a Mac 500 Determination Analyzer,

Char was first produced from the dried coal product and proximate analysis done with the volatiles at 13.4 percent. This char was then used to make coke. The coke made from the Western SynCoal product was analyzed with the following results:

Test 1

Western SynCoal Char, \% 25

Western SynCoal Coal, \% 25

Coke Breeze, \% 25

Pitch, \% 10

Binder Coal, \% 10

Coal Tar, \% 5 


\section{Product Analysis}

Moisture, \% 0.65

Ash, \% 12.12

Volatile, \% 1.32

Fixed' Carbon, \% $\quad 85,91$

CSR 0.0

CRI $\quad 70.43$

Drop Shatter, \% $\quad 72.13$

\section{Test 2}

Western SynCoal Char, \% $\quad 50$

Western SynCoal Coal, \% 23

Coke Breeze, \% 12

Pitch, \% 15

Binder Coal, \% 10

\section{Product Analysis}

Moisture, \% 0.82

Ash, \% 11.77

Volatile, \% $\quad 1,42$

Fixed Carbon, \% $\quad 85.99$

CSR 1.19

CRI $\quad 66.12$

Drop Shatter, \% 94.62

$\underline{\text { Test } 3}$

Western SynCoal Char, \% $\quad 50$

Western SynCoal Coal, \% 30

Coke Breeze, \% 10

Pitch, \% 10

Product Analysis

Moisture, \% $\quad 0,71$

Ash, \% $\quad 12.02$

Volatile, \% 1.10

Fixed Carbon, \% $\quad 87.27$

CSR $\quad 1.10$

CRI $\quad 71.19$

Drop Shatter, \% $\quad 96.40$ 
The goal of this project was to enhance Western SynCoal's coal into a usable coke product. The coke produced could be used in a cupola operation as a carbon enhancer or for a fuel in the cement or sugar beet furnace to replace conventional coke. Although the CSR and CRI are not to industry standards for the blast furnace industry, the cokes have an excellent drop shatter index. The large size retention is of the utmost importance for the cupola, cement or sugar beet industry.

1996:

A 500-pound sample of green briquettes was taken to Swindell Dressier for testing in a shuttle kiln. This test was conducted on January 23 and monitored by CTC personnel. The test succeeded in producing quality coke and providing the concept of a shuttle or tunnel kiln. Plans are to burn the volatiles from the coke which will be economically attractive. In parallel an available shuttle kiln was evaluated for coking the 40-ton sample to ship to General Motors. This kiln was originally designed for curing pottery. The capacity is one ton per cycle.

An eight ton test was conducted at a working cupola with very favorable results. This test was run using 50 percent CTC continuous coke and 50 percent conventional coke. In this run, temperature was maintained at desirable levels and carbon pickup was normal. No negative characteristics were detected. This test further proved the acceptability of CTC continuous coke in the cupola and helped reduce any perceived risk.

In the first half of 1996 most of the man-hours were spent producing the 20 tons of coke for the General Motors' cupola test. The task went well but was very labor intensive. All the raw materials had to be dried, crushed, weighed, and blended before they were briquette. In demonstration quantities, as designed, the PDU process is well suited. In large quantities the PDU process 'is too labor intensive to be efficient. In making this test sample many quality factors were closely monitored, Some of the factors are:

Raw material recipe

Moisture

Particle size

Blending time

Briquetting temperature

Briquetting roll speed

Calcining heat profile

In addition, there were many delays caused by breakdowns and bad weather. The coke shipped April 15 for testing on April 17.

The test was done in the production cupola at the Defiance, Ohio, plant and was monitored by CTC and General Motors' personnel. The Coal Technology form coke was 
charged into the \#3 cupola from 0:13 a.m. to 4:04 p.m. Formed coke was charged as 12,5 percent of the fuel/carburizer requirement from 0:13 a.m. to 9:28 a.m. or 62 charges, 25 percent from 9:34 a.m. to 2:59 p.m. or 38 charges and 50 percent from 3:04 p.m. to 4:04 p.m. or 13 charges, A total of 113 charges containing CTC form coke were consumed during the production trial. Fifteen charges represent about I-1/2 hours of melting time in this cupola, so about 11 hours 18 minutes of actual melting time occurred with CTC form coke as part of the total fuel/carburizer requirement. The iron temperature and iron composition data indicated that the form coke performed satisfactorily. In fact, no change in the way the cupola performed was noticed. Based on observations made during the Defiance trial and an analysis of the data, GM was interested in pursuing the controlled research test.

On Monday, August 19, 1996, the bed coke was placed into the cupola. One (1) wooden pallet was placed in the bottom of the cupola, $5000 \mathrm{lbs}$. of formed coke placed in the middle with one (1) pallet and another $5000 \mathrm{lbs}$. to make the bed. The gas heat lances were started at 5:00 p.m. and were located at the front of the cupola in the tap hole and at the rear at the clean out door. These heat lances were fired the entire night and at 6:00 a.m. on Tuesday, August 20,1996, the burn in of the coke bed was determined to be complete. Another $500 \mathrm{lbs}$. of formed coke were added to obtain the correct bed height. At 6:45 a.m. the air at the tuyeres were turned on to allow the last $500 \mathrm{lbs}$. charge of formed coke to stabilize. At 7:00 a.m. the charging of the cupola began. Ten charges were loaded into the cupola and at 7:58 a.m. the hot blast started. At 8:08 a.m. the heat lance located in the tap hole was removed. At 8:12 a.m. on August 20, the tap off was accomplished, molten iron flowing from the cupola into the pouring ladle. At 8:16 a.m. the first pig was poured (pig) (molten iron formed into solid bars). The first temperature reading was $2870^{\circ} \mathrm{F}$ and remained constant throughout the run.

Slagging started at 9:20 a.m. (slaggings - impurities in the molten iron). Slagging must occur. This tells the operator that the cupola is starting to balance out. At 9:42 the cupola was flowing beautifully, Temperature readings were excellent. Back pressures were low and constant. (Back pressures tells the operator if coke is holding its shape and holding the burden of the material.) If coke collapses, air will not penetrate the bed and pressure rises actually blowing the molten iron out the tap hole which is a very dangerous situation. A total of 61 charges were run on August 20. When the conventional coke was run prior to the formed coke, charging rates were 10 charges per hour. The formed coke charges were 11 to 12 charges per hour. This equates to a higher melt rate per hour of material. Equilibrium was obtained and held for four hours with no problems incurred. GM and Pellestar personnel were very pleased with the run. The bed coke from CTC was left in the cupola to be fired for the next run day.

A formal paper will be written by the combined group of GM and CTC engineers and published for the industry and the world to know that CTC and DOE accomplished their goal to make quality coke in a non-polluting and economically feasible way. 
In parallel with the General Motors' cupola test coke production, equipment was evaluated for use in a commercial plant. Two tunnel kilns were studied from Bristol and then visited at Frankfort, Kentucky. These kilns appear to be well suited for a commercial plant of about 15,000 tons per year production, Also, other briquetting techniques were evaluated. Presently CTC coke is made on a roll briquette. This briquetting technique works reasonably well but possibly a type of press could be better. CTC is negotiating with several vendors to test this press technique.

The only successful conclusion of several years of CTC-DOE formed coke development work is building a commercial plant. It is anticipated that this will occur in the near future. 


\section{APPENDIX}

Figure 1 Char (Briquette) Coking Facility

Figure 2 Crushing Strength vs. \% Coal and \% Pitch at 5,000 Lb. Briquetting Pressure and $0.59 \mathrm{~mm},-30$ Mesh

Figure 3 Photograph of Briquette Machine

Figure 4 Photograph of Briquette Machine

Figure 5 Moisture Volatile

Figure 6 Weight Loss vs. Temperature

Figure 7 Photomicrographs of Char From Coal Technology Corporation's Twin Screw Carbonize

Figure 8 Photomicrographs of Coke Briquette From Coal Technology Corporation's Form Coke Process

Figure 9 Photomicrographs of Macerals in High Volatile Bituminous Knox Creek Coal From Coal Technology Corporation

Figure 10 Photomicrographs of Macerals in Medium Volatile Bituminous Sewell Coal From Coal Technology Corporation

Figure 11 Coal Petrographic Associates, Inc., Composition - Balance Index/

Figure 12 CTC Cokemaking, First Process Step

Figure 13 CTC Cokemaking, Second Process Step

Table 1 Analysis of Coke Briquettes From Char Coker Test \#4

Table 2 Chemical Test Results for CTC Research Char Coker Samples

Table 3 Physical Test Results for CTC Research Char Coker Samples

Table 4 Coke Reactivity Test Results for Coal Technology Corporation Formed Coke Sample 


\section{APPENDIX (Continued)}

Table 5 Coke Reactivity Test Results for Coal Technology Corporation Formed Coke Sample

Table 6 Proximate Analysis and Sulfur Content of the Indicated Green Briquettes and Cokes

Table $7 \quad$ Physical Properties of the Indicated Cokes and Briquettes

Table $8 \quad$ Coke Reactivity Test Results from the Japanese "i" Test for Coke Strength after Reaction (CSR) and Coke Reactivity Index (CRI) for Indicated Coke Samples

Table 9 Proximate Analysis and Sulfur Content of the Indicated Coal Samples

Table 10 Gieseler Plastometer, Arnu Dilatometer and Free-Swelling Index Test Results of the Indicated Coal Samples

Table 11 Petrographic Maceral Composition of the Indicated Coal Samples

Table 12 Coal Technology Corporation, Japanese Method Coke Reactivity (CRI) and Strength After Reaction (CSR) Testing

Table 13 CTC/CLC Coke's Quality Data With Various Feed Coals 


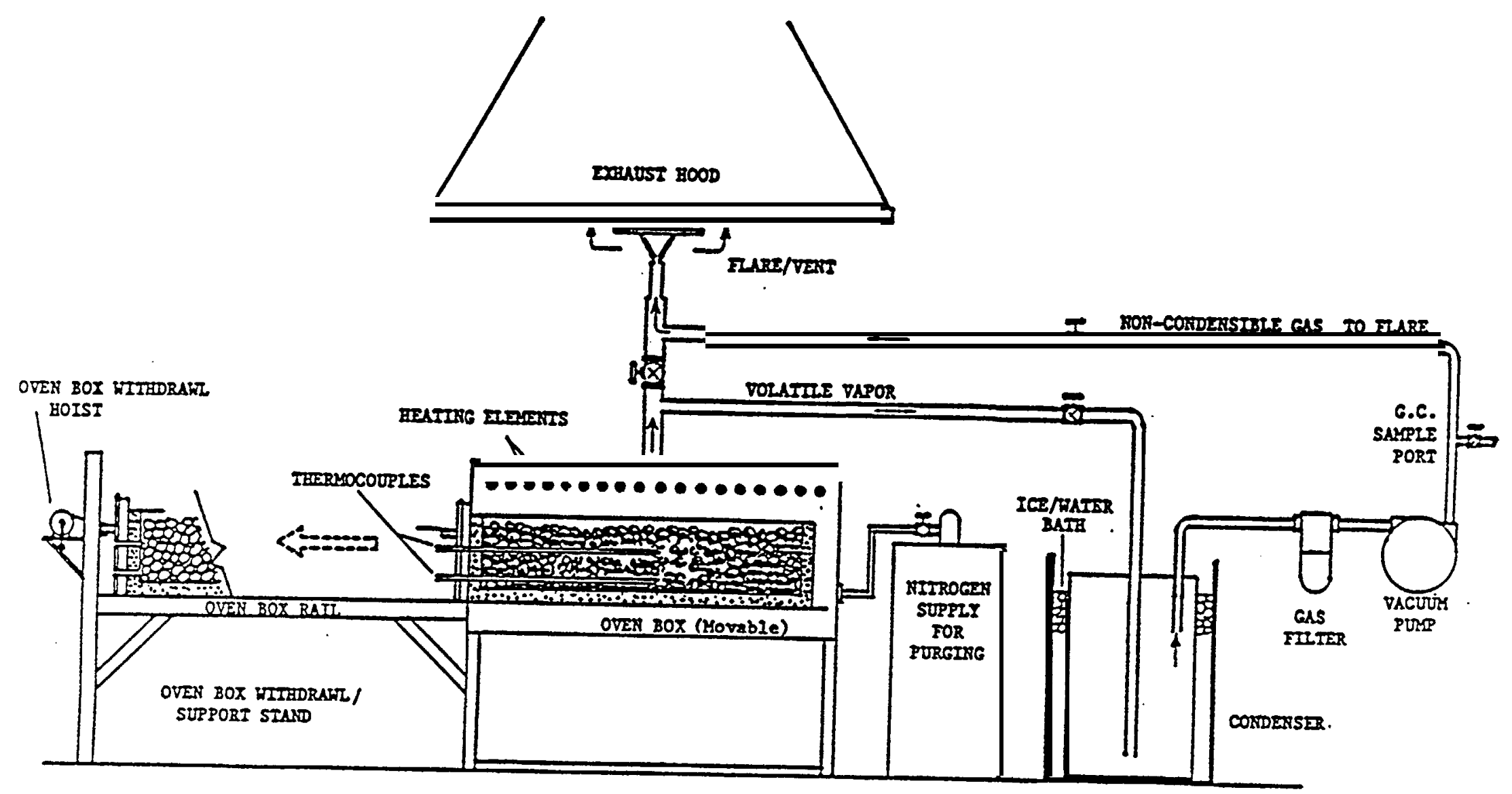

Figure 1. Bench-Scale coke Oven 


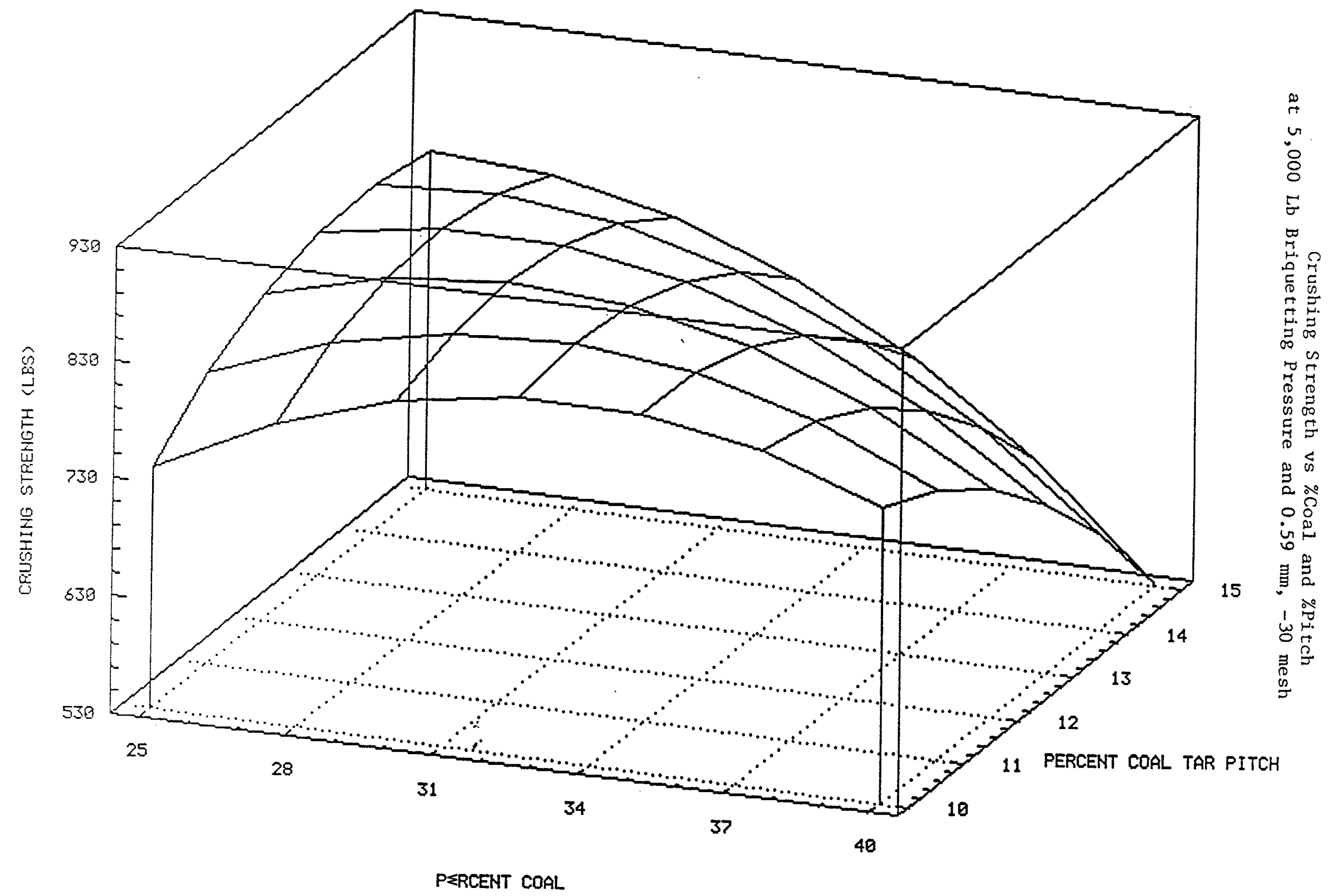

Figure 2. 


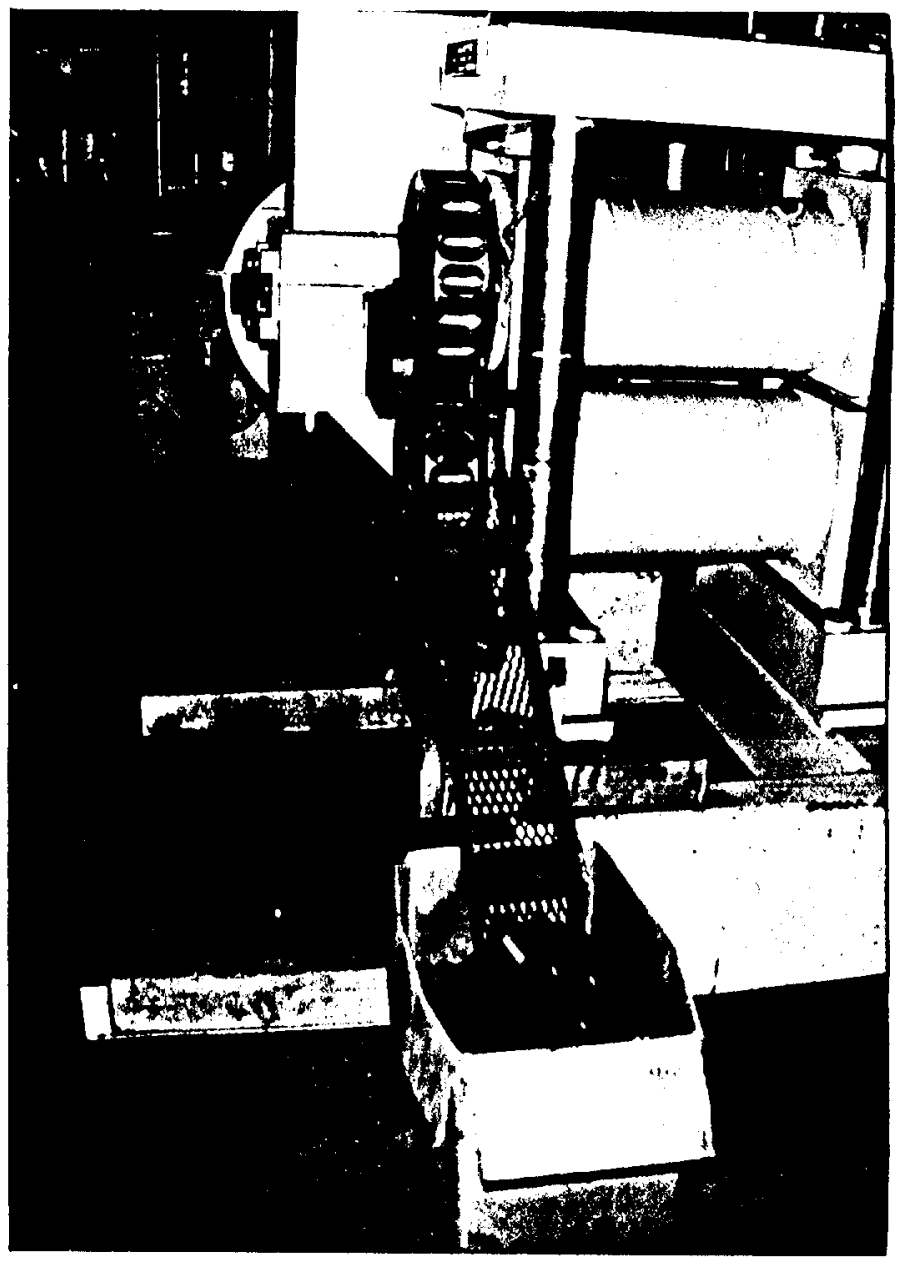

Figure 3 Photograph of Briquette Machine Producing Briquettes

Figure $4 \quad \begin{aligned} & \text { Photograph of Briquette Machine } \\ & \text { Producing Briquettes }\end{aligned}$

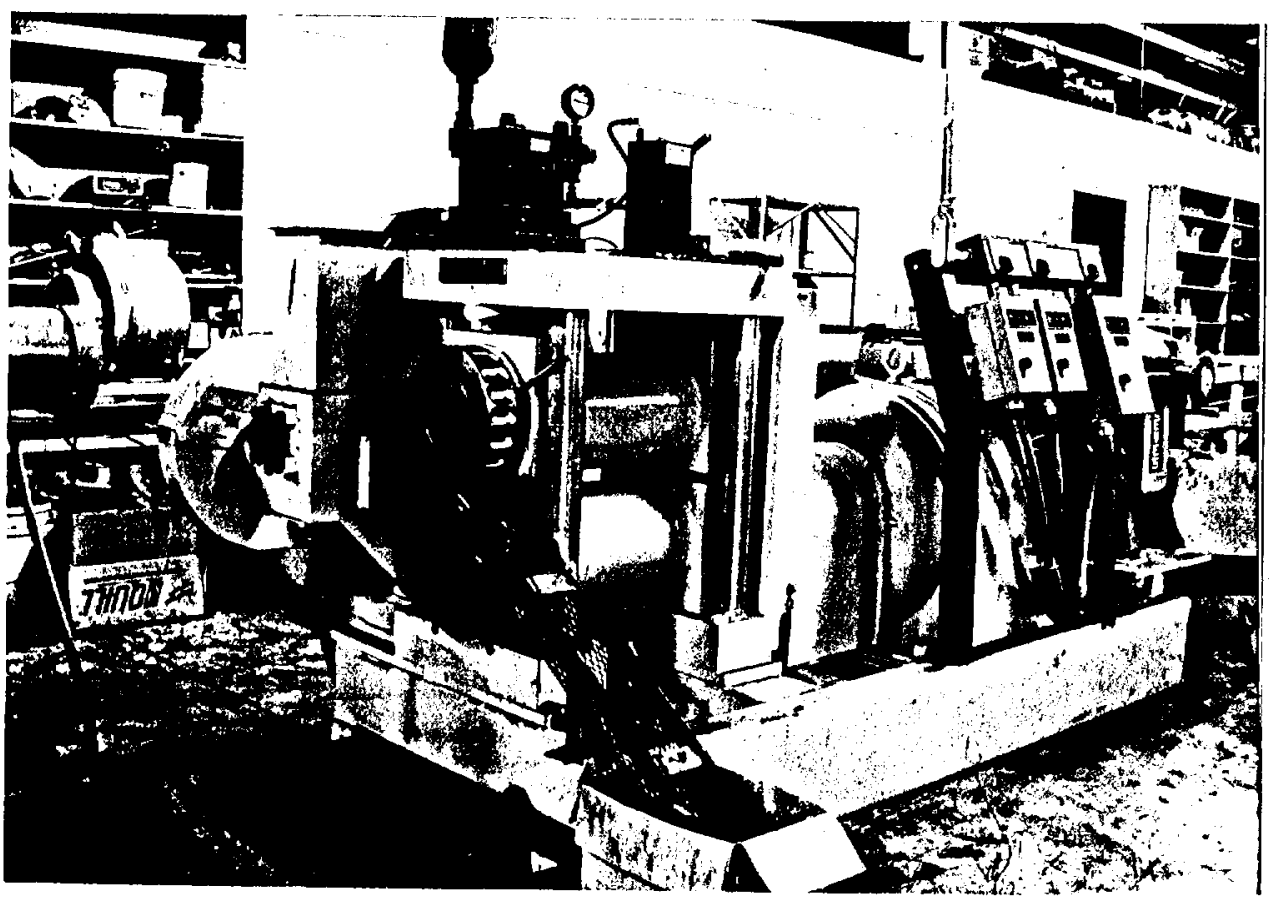


$\because \quad$ MOISTURE YOLATILE

Date: Apr. 21, 1992

Elapsed Time: :2:13:00

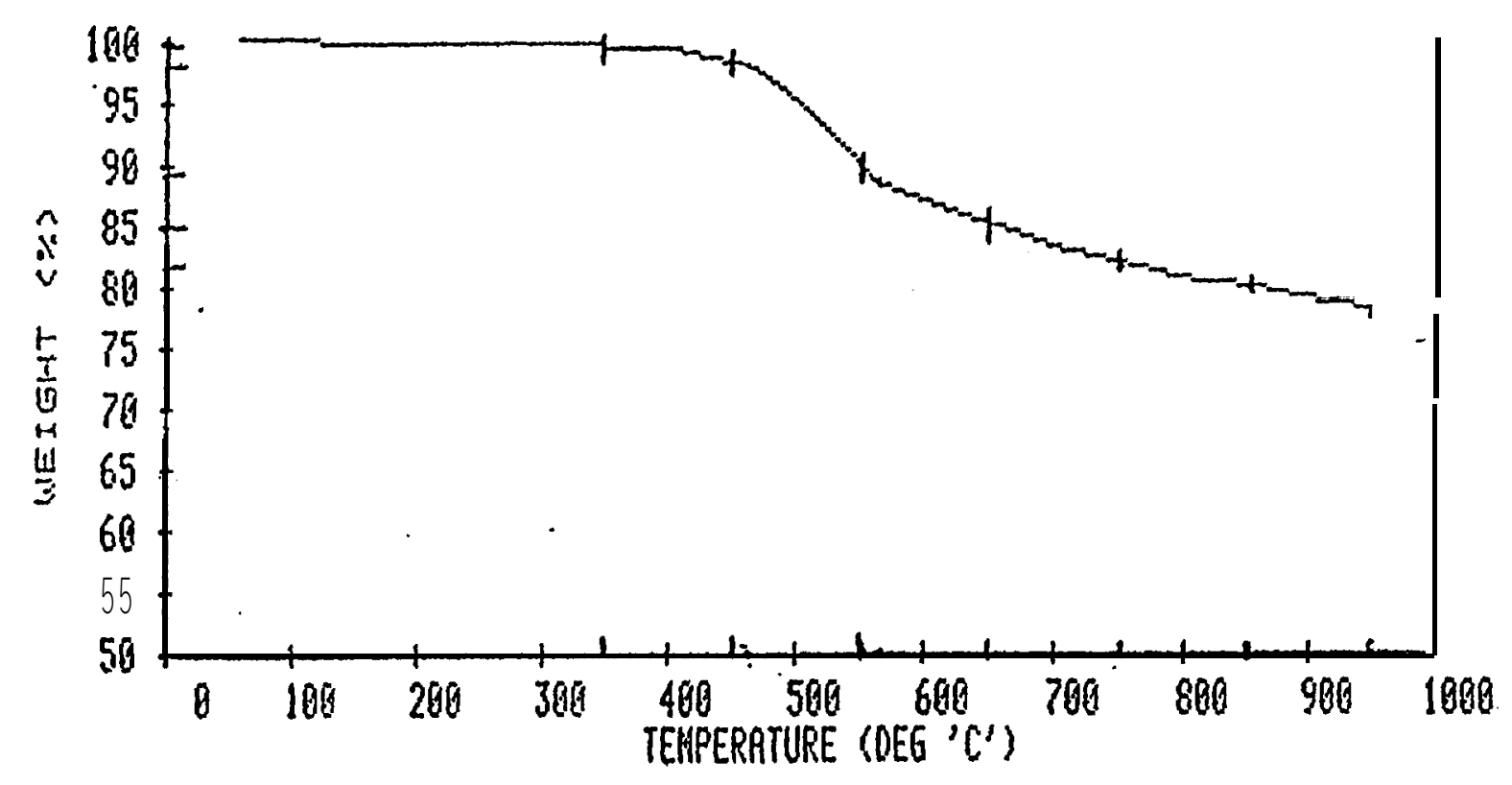

Frn.\#1 Cr.\#6 Tyge:Claseification. IQ:KNOX CRK- Weight: Q.730 Gramle!

Title: MOISTURE VOLATILE Zero DeY: 10 Max DeY: 5

Mas Cyr Remp Final Model Step End Timeout or

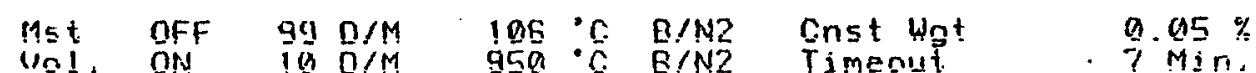

FIGURE 5 


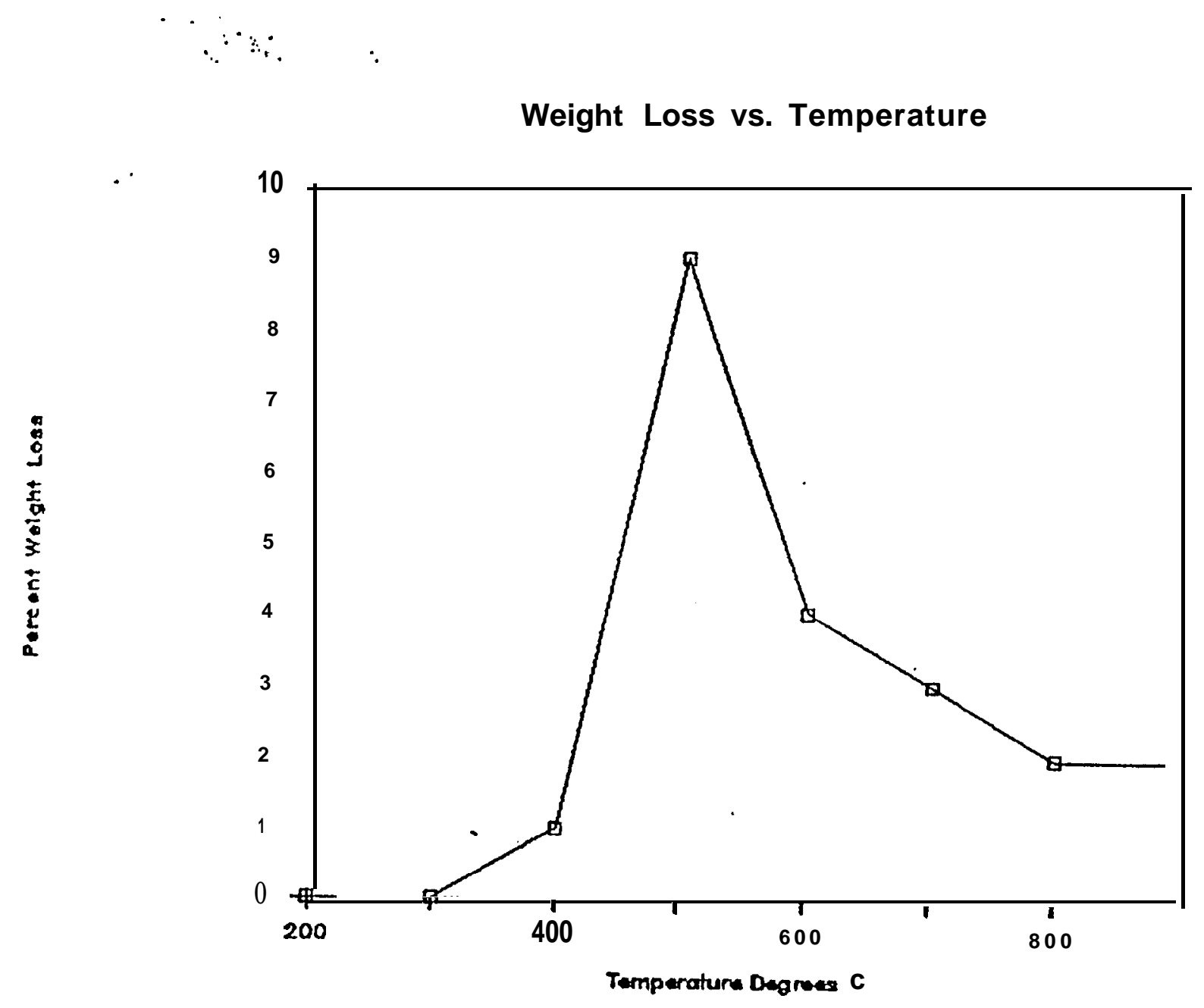

FIGURE 6 

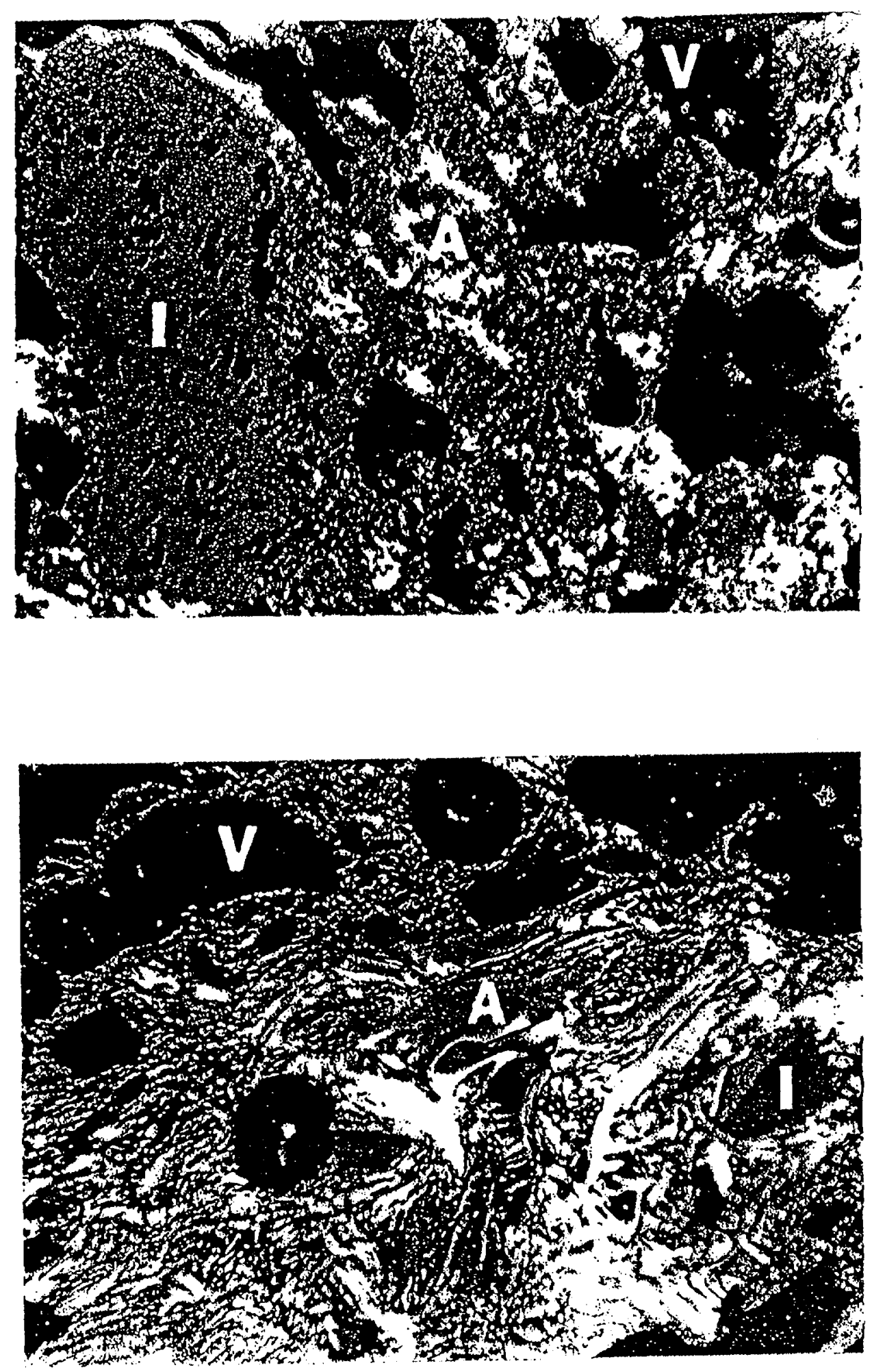

FIGURE 7: PHOTOMICROGRAPHS OF CHAR FROM COAL TECHNOLOGY CORPORATIONS' TWIN CREW CARBONIZE SHOWING CHAR IN POLARIZED LIGHT WHERE A=ANISOTROPIC BINDER CARBON, I=ISOTROPIC INERT FILLER CARBON AND V=VOIDS

REFLECTED POLARIZED LIGHT WITH TINT PLATE IN OIL, $x 450$ 

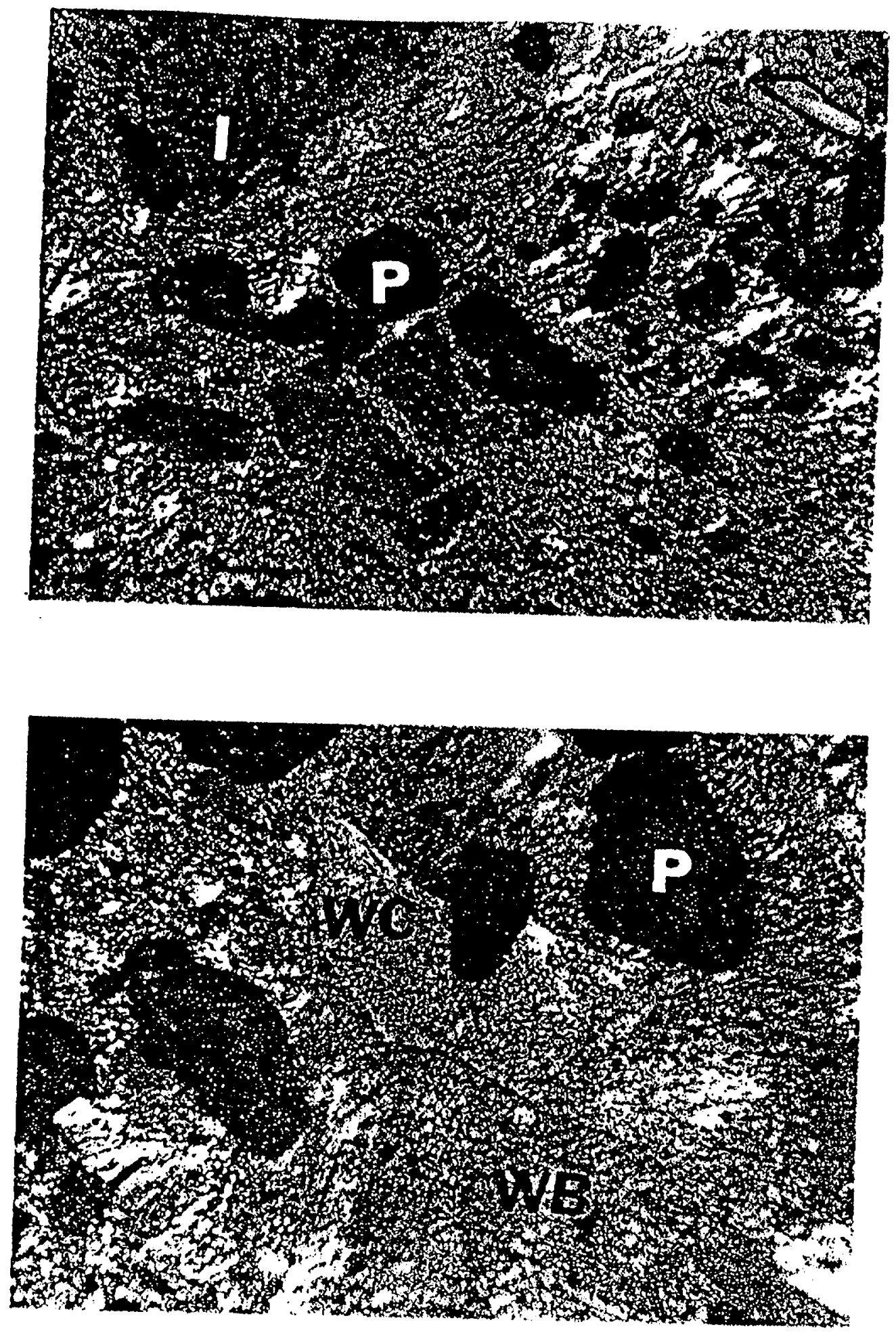

FIGURE 8:

PHOTOGRAPHS OF COKE BRIQUETTE FROM COAL TECHNOLOGY CORPORATIONS' FORMCOKE PROCESS SHOWING: WC=ANISOTROPIC CHAR IN COKE WALLS, WB=ANISOTROPIC BINDER CARBON IN COKE WALLS, I=ISOTROPIC INERT FILLER CARBON AND P=PORES. REFLECTED POLARIZED LIGHT WITH TINT PLATE IN OIL, $\mathrm{x}=450$ 

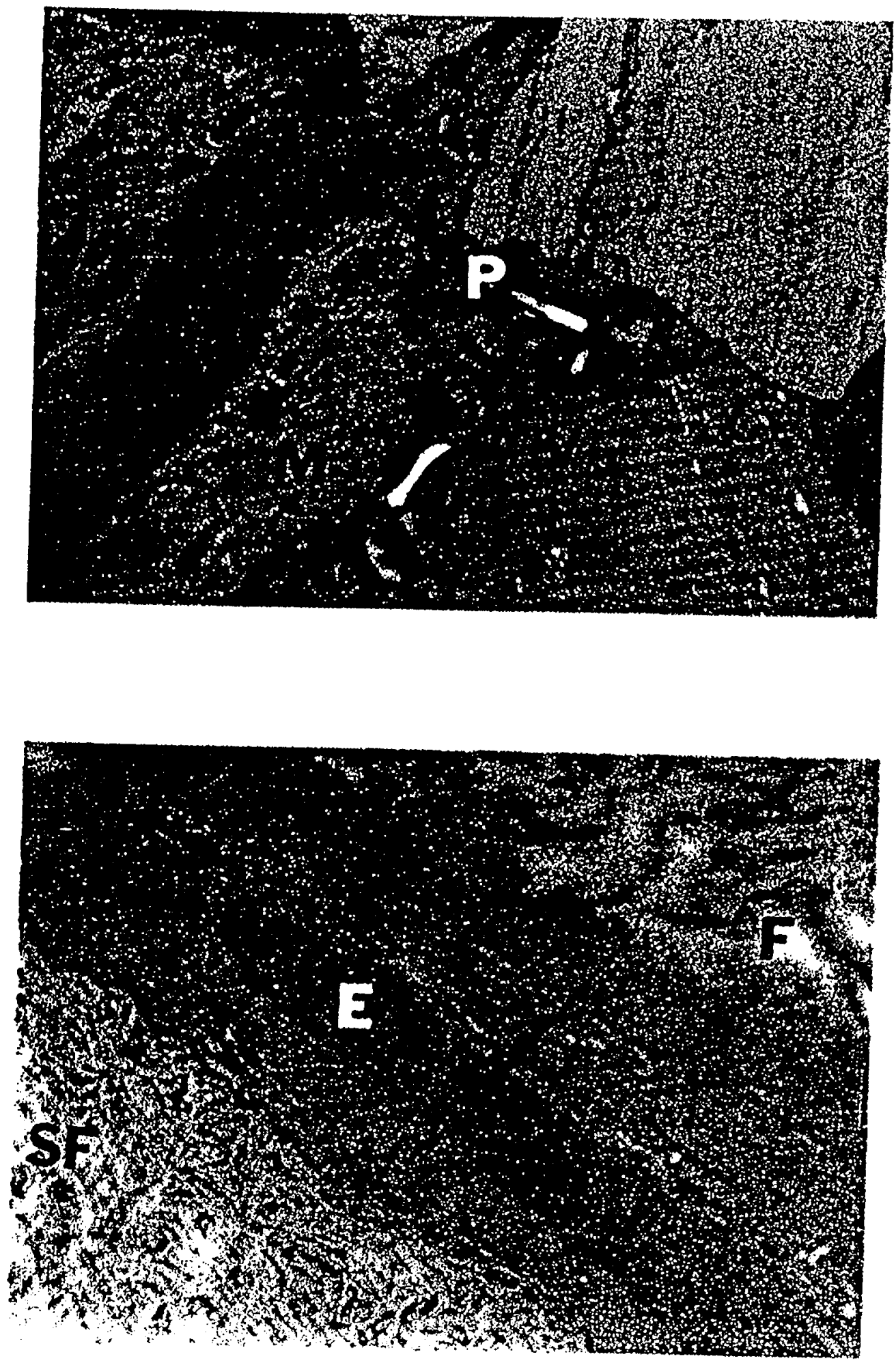

FIGURE 9: PHOTOMICROGRAPHS OF MACERALS IN HIGH VOLATILE BITUMINOUS KNOX CREEK COAL FROM COAL TECHNOLOGY CORPORATION SHOWING: V=VITRINITE, E=FXINITE, M=MICRINITE, SF=SEMIFUSINITE $\mathrm{F}=$ FUSIINITE AND P=PJASTIC MOUNTING MEDIA. REFLECTED LIGHT IN OIL, $x 450$ 

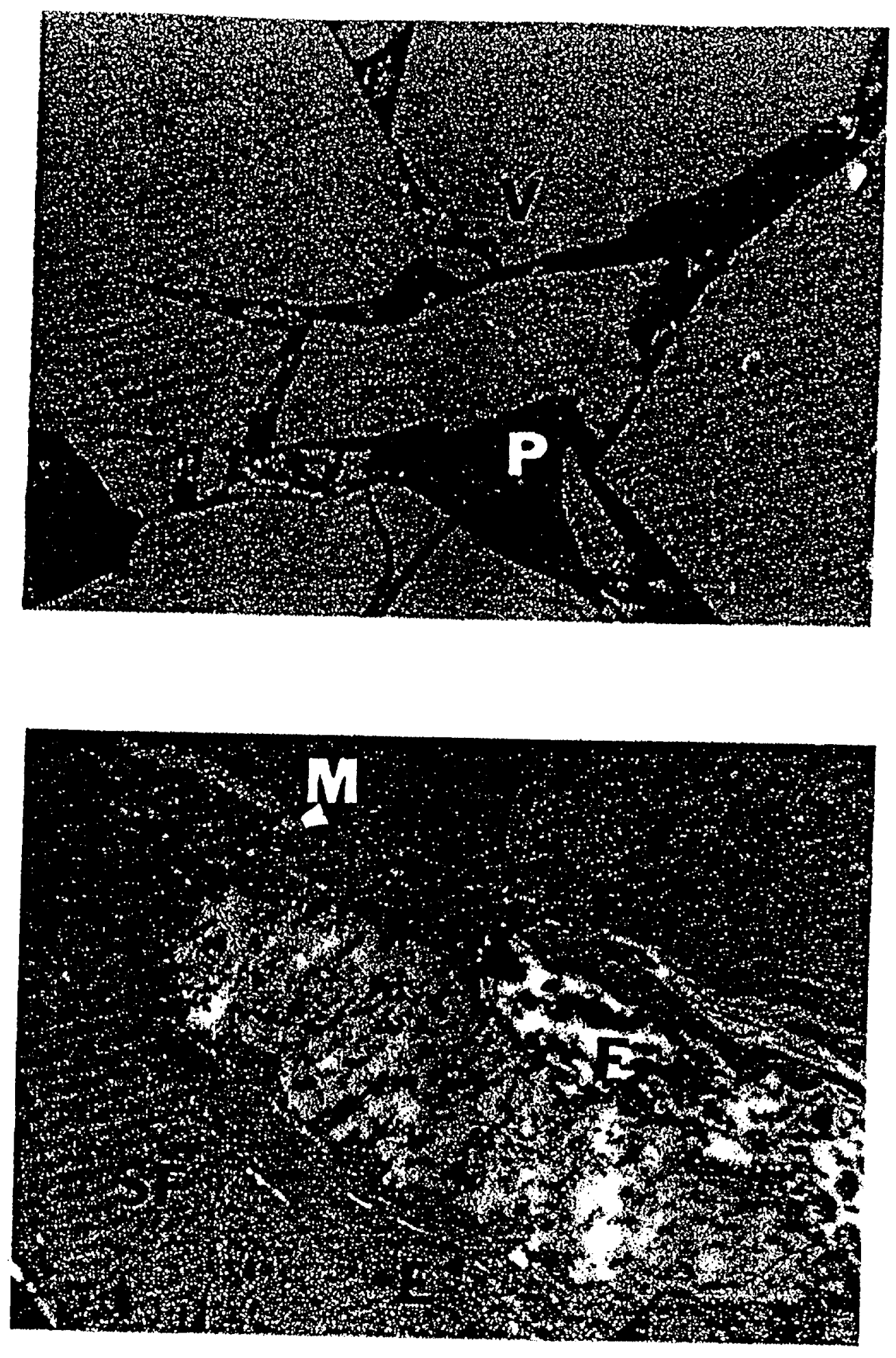

FIGURE 10 PHOTOMICROGRAPHS OF MACERALS IN MEDIUM VOLATILE BITUMINOUS SEWELL COAL FROM COAL TECHNOLOGY CORPORATION SHOWING: V=VITRINITE, E=EXINITE, M=MICRINITE, SF=SEMIFUSINITE, F=FUSINITE ANT) P=PLASTIC MOUNTING MEDIA.

REFLECTED IJIGHT IN OIL, $\mathrm{X}=450$ 

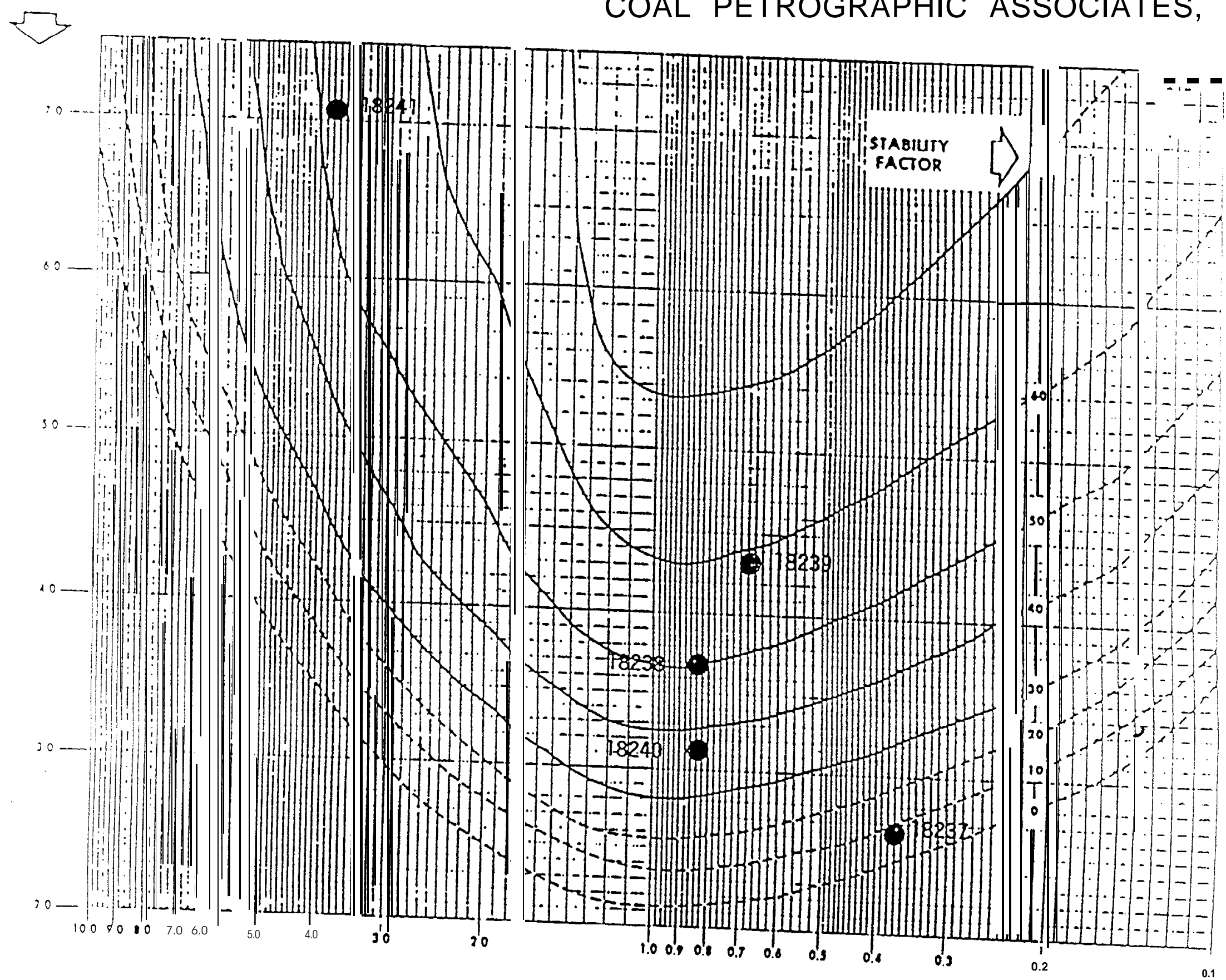

Figure 11

COMPOSITION - BALANCE INDEX 


\section{CTC COKEMAKING SECOND PROCESS STEP}

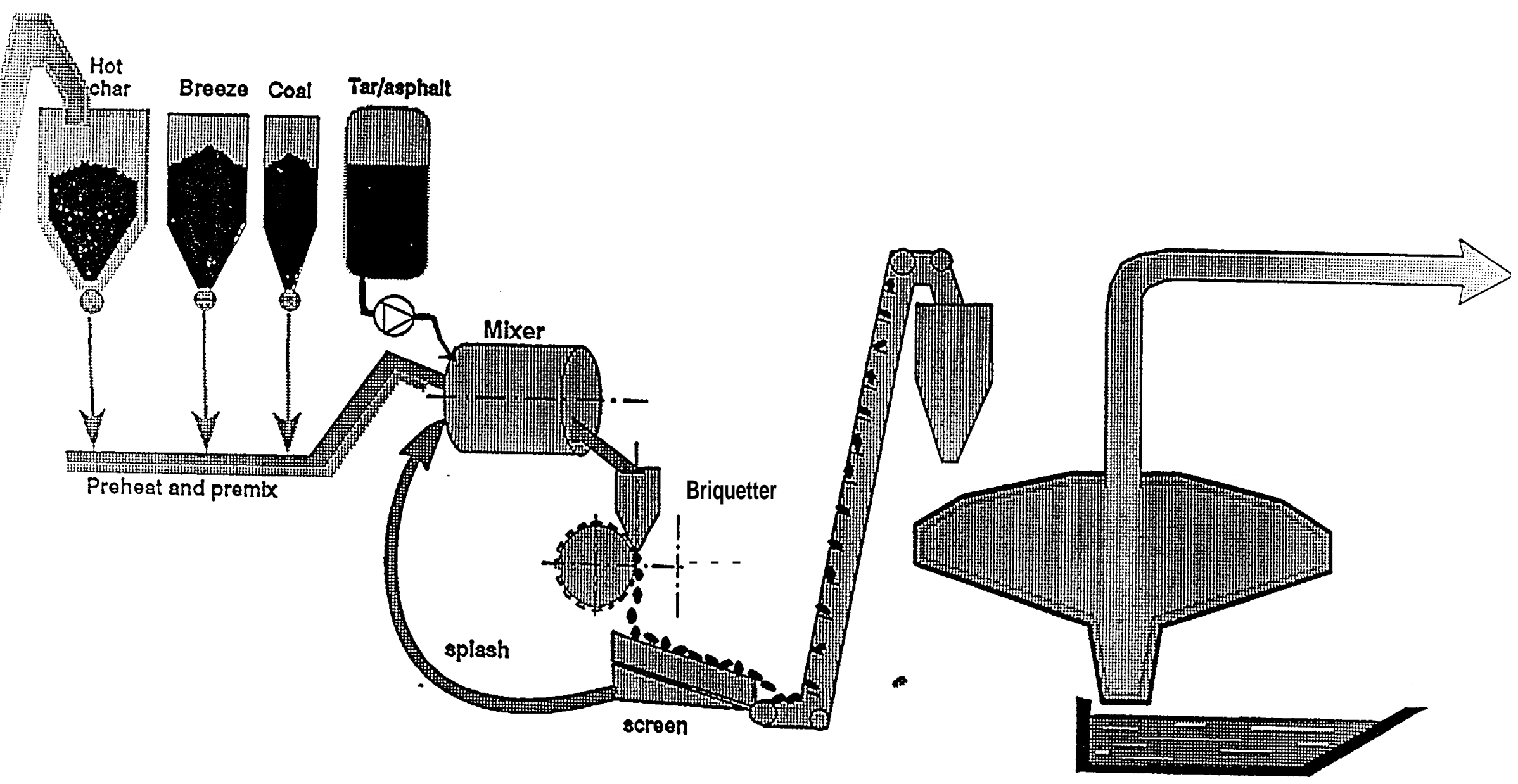


Table 1

Analysis of Coke Briquettes from Char Coker Test \#4

COKE CHEMICAL PROPERTIES

Proximate Analysis, dry wt\%

$\begin{array}{ll}\text { Volatile Matter } & 0.32\end{array}$

$\begin{array}{ll}\text { Ash } & 8.57\end{array}$

Fixed Carbon $\quad 91.11$

Ultimate Analysis, dry wt\%

$\begin{array}{ll}\text { Carbon } & 89.70\end{array}$

Hydrogen $\quad 0.16$

$\begin{array}{lr}\text { Nitrogen } & 0.67\end{array}$

Oxygen $<0.10$

$\begin{array}{ll}\text { Sulfur } & 0.91\end{array}$

$\begin{array}{ll}\text { Ash } & 8.56\end{array}$

$\begin{array}{ll}\text { Calorific Value, Btu/lb (dry) } & 12,966\end{array}$

Japanese Coke Reactivity Test

Coke Reactivity Index, CRI 46.3

Coke Strength After Reaction, CSR 2.0

COKE PHYSICAL PROPERTIES

Modified Tumbler Test $(1.5 \times 1$ inch -500 rev.)

Modified Stability Factor (+0.75 inch) 9.3*

Modified Hardness Factor (+0.25 inch) 47.1

$\begin{array}{ll}\text { Apparent Specific Gravity } & 1.26\end{array}$

$\begin{array}{ll}\text { True Specific Gravity } & 1.86\end{array}$

$\begin{array}{lr}\text { Porosity, } \frac{\circ}{0} & 32.3\end{array}$

* Tumbler test was performed in duplicate, with the results averaged. 
Table 2 ,

Chemical Test Results for CTC Research Char Coker Samples

Char Coker ID No.

UEC NO.

$\frac{\text { Proximate Analysis, } \% \text { (dry) }}{-}$ Volatile Matter

Ash

Fixed Carbon

ultimate Analysis, \%(dry)

C

$N$

0

$\mathrm{S}$

Ash

Calorific Value, Btu/lb (dry)

$\frac{\text { Japanese Coke Reactivity Test }}{\text { Coke Reactivity Index, CRI }}$

Coke Strength After Reaction, CSR
9

10

8931

8915

11

8929

12

8930

$\begin{array}{rrrr}0.41 & 0.30 & 0.43 & 0.47 \\ 7.33 & 7.33 & 7.61 & 7.34 \\ 92.26 & 92.37 & 91.96 & 92.19\end{array}$

$\begin{array}{rrrr}89.01 & 90.59 & 88.86 & 89.16 \\ 0.38 & 0.42 & 0.41 & 0.56 \\ 0.72 & 0.76 & 0.75 & 0.75 \\ 1.65 & 0.26 & 1.65 & 1.39 \\ 0.82 & 0.81 & 0.79 & 0.82 \\ 7.42 & 7.16 & 7.54 & 7.32\end{array}$

13,41

13,253

13,239

13,269

37.3

30.5

35,1

32.9

38.8

26.0

36.3

31.2 
Table 3

Physical Test Results' for CTC Research Char Coker Samples

Char Coker id No.

UEC NO.

ASTM Tumbler Test (one test only)

Stability Factor

Hardness Factor

Apparent Specific Gravity

$\underline{\text { True Specific Gravity }}$

Calculated Porosity, \%
$9 \quad 10$

11

12

8931

8915

8929

8930

61.1

63.3

64.8

66.7

33.4

46.2

57.4

60.9

1.202

1.196

1.168

1.196

$1.8 \mathrm{~S}$

1.85

1.87

1.83

35.1

35.4

37.5

34.6 
Table 4

Coke Reactivity Test Results for Coal Technology Corporation Formed Coke Sample

\section{(UEC Project No. 280)}

Coke ID:

Briquette $\# 36$

UEC No.:

12223

JAPANESE COKE REACTIVITY TEST

Coke Reactivity Index, (CRI), q

31.0

Coke Strength-After-Reaction (CSR), 웅

62.1 
Table 5

Coke Reactivity Test Results for Coal Technology . " corporation Formed Coke Sample (UEC Project No. 280)

Coke ID:

UEC NO.:

19852

JAPANESE_COKE_REACTIVITY TEST

Coke Reactivity Index (CRI), \%

30.4

Coke Strength After Reaction (CSR), \%

67.0 
Table 6

Proximate Analysis and Sulfur Content of the Indicated Green Briquettes and Cokes

\begin{tabular}{||l|c|c|c|c||}
\hline \multirow{2}{*}{ SAMPLE I.D. } & \multicolumn{2}{|c||}{ PROXIMATE ANALYSIS, WT. \% (DRY) } & $\begin{array}{c}\text { TOTAL SULFUR, } \\
\text { WT.\% (DRY) }\end{array}$ \\
\cline { 2 - 5 } & VOLATILE MATTER & FIXED CARBON & ASH & 0.87 \\
\hline $\begin{array}{l}\text { GREEN BRIQUETTES } \\
\text { RJG\# 16351 }\end{array}$ & 19.32 & 74.19 & 7.94 & 0.83 \\
\hline $\begin{array}{l}\text { CTC COKED } \\
\text { RJG\# 16452 }\end{array}$ & 2.42 & 90.06 & 8.34 & 0.96 \\
\hline $\begin{array}{l}\text { UEC COKED } \\
\text { RJG\# 16480 }\end{array}$ & 0.81 & 90.85 & 8.92 & 0.83 \\
\hline $\begin{array}{l}\text { COMMERCIAL COKE } \\
\text { RJG\# 16357 }\end{array}$ & 0.36 & 90.72 & & \multirow{2}{*}{} \\
\hline \hline
\end{tabular}

Table 7

Physical Properties of the Indicated Cokes and Briquettes

\begin{tabular}{|c|c|c|c|c|c|c|c|}
\hline & \multicolumn{2}{|c|}{ MODIFIED } & \multirow{2}{*}{$\begin{array}{l}\text { APP.SP. } \\
\text { GRAVITY }\end{array}$} & \multirow{2}{*}{$\begin{array}{l}\text { TRUE } \\
\text { SP. GR. }\end{array}$} & \multirow{2}{*}{ POROSITY } & \multicolumn{2}{|c|}{ CPA $^{*}$} \\
\hline & STABILITY & HARDNESS & & & & & \\
\hline $\begin{array}{l}\text { CTC COKED } \\
\text { RJG\# } 16452\end{array}$ & 77.9 & 78.7 & 1.25 & 1.90 & 34.7 & 46.4 & 1.15 \\
\hline $\begin{array}{l}\text { UEC COKED } \\
\text { RJG\# } 16480\end{array}$ & 72.2 & 82.1 & 1.21 & 1.96 & 38.3 & 42.6 & $1.02 / 1.09$ \\
\hline $\begin{array}{l}\text { COMMMERCIAL } \\
\text { COKE } \\
\text { RJG\# } 16357\end{array}$ & 79.0 & 85.0 & 0.93 & 2.06 & 54.9 & - & 0.98 \\
\hline $\begin{array}{l}\text { GREEN } \\
\text { BRIQUETTES }\end{array}$ & & & & & & 56.0 & 1.24 \\
\hline
\end{tabular}

Table 8

Coke Reactivity Test Results from the Japanese "I" Test for Coke Strength after Reaction (CSR) and Coke Reactivity Index (CRI) for Indicated Coke Samples

\begin{tabular}{|c|c|c|}
\hline SAMPLE I.D. & COKE REACTIVITY INDEX (CRI) & COKE STRENGTH AFTER REACTION (CRI) \\
\hline CTC COKED RJG\# 16452 & 33.3 & 51.9 \\
\hline UEC COKED RJG\# 16451 & 32.8 & 55.1 \\
\hline COMMERCIAL COKE RJG\# 16357 & 28.4 & 55.6 \\
\hline
\end{tabular}




\title{
COAL PETROGRAPHIC ASSOCIATES, INC.
}

\author{
Table 9
}

Proximate Analysis and Sulfur Content of the Indicated Coal Samples 1)

\begin{tabular}{lllllll} 
Sample I.D. & $\begin{array}{c}\text { Volatile } \\
\text { Matter } \\
\text { daf 2) }\end{array}$ & $\begin{array}{l}\text { Proximate } \\
\text { Volatile } \\
\text { Matter }\end{array}$ & $\begin{array}{l}\text { Analysis, Wt. \% (dry) } \\
\text { Carbon }\end{array}$ & $\begin{array}{l}\text { Total } \\
\text { Sulfur, }\end{array}$ & $\begin{array}{l}\text { Ash } \\
\text { Ct. \% } \\
\text { Consol }\end{array}$ \\
\cline { 2 - 3 } $\begin{array}{l}\text { Rend Lake } \\
\text { CPA\# 18237 }\end{array}$ & 36.27 & 34.20 & & 60.10 & 5.70 & 0.80
\end{tabular}

Maple Creek

Pittsburgh

Seam 18240

37.72

35.19

58.10

$6.71 \quad 1.50$

Koppers

CPA\# 18238

33.59

31.68

62.62

$\begin{array}{ll}5.70 & 0.70\end{array}$

Lady H Mine

Sewell

CPA\# 18239

28.59

27.49

68.66

$3.85 \quad 0.85$

Pinnacle

Pocahontas \#3

Seam

CPA\# 18241

$\begin{array}{lllll}18.01 & 17.05 & 77.62 & 5.33 & 0.65\end{array}$

1) As determined by Coal Technology Corp.

2) Dry, ash-free volatile matter 
Table 10

Gieseler Plastometer, Arnu Dilatometer and Free-Swelling Index Test Results of the Indicated Coal Samples

\begin{tabular}{|c|c|c|c|c|c|}
\hline $\begin{array}{l}\text { Coal } \\
\text { CPA\# }\end{array}$ & $\begin{array}{l}\text { Consol } \\
\text { Rend Lake } \\
18237 \\
\end{array}$ & $\begin{array}{l}\text { Maple Creek } \\
\text { Pgh Seam } \\
\mathbf{1 8 2 4 0} \\
\end{array}$ & $\begin{array}{l}\text { Koppers } \\
18238 \\
\end{array}$ & $\begin{array}{l}\text { Lady } \mathrm{H} \\
\text { Sewel1 Seam } \\
18239 \\
\end{array}$ & $\begin{array}{l}\text { Pinnacle } \\
\text { Pocahontas \#3 Seam } \\
18241\end{array}$ \\
\hline \multicolumn{6}{|l|}{ Gieseler Plastometer } \\
\hline Maximum Fluidity, ddpm & 0 & 29,984 & 4,824 & 1,174 & 8 \\
\hline Maximum Fluidity Temp., deg C & $N A^{\star}$ & 441 & 445 & 452 & 485 \\
\hline Softening Temp., deg C & $\mathrm{NA}$ & 388 & 402 & 398 & 455 \\
\hline Solidification Temp., deg C & NA & 484 & 488 & 496 & 507 \\
\hline Plastic Temp. Range, deg C & NA & 96 & 86 & 98 & 52 \\
\hline \multicolumn{6}{|l|}{ Arru Dilatometer } \\
\hline Percent Dilation & -30 & +197 & +113 & +125 & +13 \\
\hline Percent Contraction & -30 & -26 & -26 & -29 & -27 \\
\hline Initial Softening, deg $\mathrm{C}$ & 375 & 369 & 372 & 381 & 429 \\
\hline Initial Dilation, deg C & 429 & 411 & 426 & 432 & 471 \\
\hline Maximum Dilation, deg C & NA & 453 & 456 & 468 & 495 \\
\hline Free-Swelling Index & 3.5 & 7.5 & 7.5 & 8.5 & 8.0 \\
\hline
\end{tabular}


Table 11

Petrographic Maceral Composition of the Indicated Coal Samples

\begin{tabular}{lr} 
Coal & \\
CPA. & \\
Reactives & \\
\hline Vitrinoid Type & 5 \\
& 6 \\
& 7 \\
& 8 \\
& 9 \\
& 10 \\
& 11 \\
& 12 \\
& 13 \\
& 14 \\
& 15 \\
& 16 \\
& 17
\end{tabular}

\begin{tabular}{|c|c|c|c|}
\hline $\begin{array}{l}\text { Consol } \\
\text { Rend Lake } \\
18237\end{array}$ & $\begin{array}{l}\text { Maple Creek } \\
\text { Pgh Seam } \\
78240 \\
\end{array}$ & $\begin{array}{l}\text { Koppers } \\
18238\end{array}$ & $\begin{array}{l}\text { Lady H } \\
\text { Sewel J Seam } \\
18239\end{array}$ \\
\hline
\end{tabular}

Pinnacle

Pocahontas \#3 Seam 18241

3.9

39.1

28.9

6.3

70.2
43.7
13.7
0.7

1.3

16.3

31.9

$0.4^{7}$
32.1
8.8

Exinoids

Resinoids

Semifusinoids

Total

\begin{tabular}{rr}
3.9 & 5.7 \\
6.5 & 0.9 \\
7.0 & 2.6 \\
\hline 89.6 & $\frac{27.5}{77.5}$
\end{tabular}

5.8

3.7

0.7

3.5
25.6

31.8

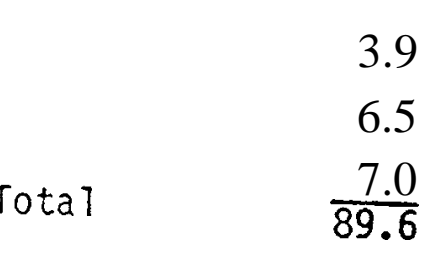

\section{7}

0.9

1.5

$\frac{3.3}{75.7}$

0.7

0.5

0.4

$\frac{2.7}{80.7}$

$\frac{2.9}{73.0}$

Inerts

Semifusinoids

Micrinoids

2.1

2.5

5.3

Fusinoids

2.5

70.6

Mineral Matter

Total

Composition Balance Index

Rank Index

Mean-Max. Ro in 0i1, \%

Calculated Stability Factor

$+\%-$
0.37
2.63
0.70
$<10$

2.5

$\frac{4.7}{22.5}$

6.6

5.5

11.3

12.0

8.5

6.9

2.4

3.6

5.8

$\frac{3.3}{24.3}$

$\frac{2.3}{19.9}$

$\frac{3.0}{27.0}$

0.81

3.21

0.86

38

0.83
3.67
0.94
50

0.67
4.37

4.31

1.12
59

3.74

7.09

1.61 
Table 12

\section{COAL TECHNOLOGY CORPORATION}

- Japanese Method Coke Reactivity (CRI) and Strength After Reaction (CSR) Testing

Coal

Koppers

Sewell

Pinnacle

Maple Creek

Rend Lake
CRI

37.7

38.7

38.2

45.6

52.4
CSR

34.5

34.4

23.1

13.3

0.0 
Table 13

\section{CTC/CLC COKE'S QUALITY DATA WITH VARIOUS FEED COALS}

\begin{tabular}{|l|l|l|l|l|c|}
\hline $\begin{array}{l}\text { Reference } \\
\text { No. }\end{array}$ & $\begin{array}{l}\text { Feed Coal } \\
\text { for Char }\end{array}$ & $\begin{array}{l}\text { Binder } \\
\text { Coal }\end{array}$ & CRI & CSR & $\begin{array}{c}\text { Analysis } \\
\text { Lab }\end{array}$ \\
\hline 36 & Hagy & H\&K & 31.0 & 62.1 & UEC \\
\hline 36 & Hagy & H\&K & 33.1 & 53.7 & NATIONAL STEEL \\
\hline 41 & Hagy & Knox Creek & 34.3 & 57.4 & UEC \\
\hline 147 & Pocahontas & Knox Creek & 30.4 & 67.0 & UEC \\
\hline 155 & Penelec Blend & Knox Creek & 34.1 & 48.9 & CTC \\
\hline 160 & Sewell & Knox Creek & 31.7 & 61.2 & CTC \\
\hline 161 & Koppers Blend & Koppers Blend & 32.8 & 53.3 & CTC \\
\hline $161 \mathrm{~A}$ & Koppers Blend & Koppers Blend & 28.8 & 58.9 & CTC \\
\hline 162 & Koppers Blend & Koppers Blend & 33.7 & 55.8 & CTC \\
\hline $162 \mathrm{~A}$ & Koppers Blend & Koppers Blend & 27.6 & 68.5 & CTC \\
\hline $162 \mathrm{~B}$ & Koppers Blend & Koppers Blend & 30.0 & 65.9 & CTC \\
\hline 167 & Poca \#3 & Koppers Blend & 34.4 & 54.3 & CTC \\
\hline 168 & Quinwood & Lady H & 35.8 & 52.2 & CTC \\
\hline 170 & Lady H & Koppers Blend & 31.3 & 63.2 & CTC \\
\hline 171 & Lady H & Koppers Blend & 34.5 & 55.2 & CTC \\
\hline 172 & Cedar Grove & Koppers Blend & 32.2 & 59.4 & CTC \\
\hline 173 & laeger Blend & laeger Blend & 33.5 & 61.9 & CTC \\
\hline 174 & Pocahontas & laeger Blend & 23.5 & 74.7 & CTC \\
\hline Large Briquette & Koppers Blend & Koppers Blend & 31.7 & 61.2 & CTC \\
\hline
\end{tabular}

